\title{
What do we know about capabilities and early internationalization? A review and synthesis
}

\author{
Eldrede T. Kahiya and Caitlin Warwood \\ School of Marketing and International Business, Victoria University of Wellington, \\ Wellington, New Zealand
}

Review and synthesis

Received 24 June 2021 Revised 27 October 2021 Accepted 25 November 2021

\begin{abstract}
Purpose - The purpose of this study is to organize and assess knowledge on the capabilities pertinent to the early internationalization of born globals (BGs) and international new ventures (INVs).

Design/methodology/approach - A systematic approach is used to search, code, organize and synthesize 155 peer-reviewed journal articles on capabilities and early internationalization.

Findings - The study delimits eight operational and five dynamic capabilities. The synthesis links capabilities to three antecedents (i.e. firm specific factors, managerial socio cognitive attributes and market factors) and three outcomes (i.e. precocity, survival and performance). While 7 of the 12 linkages identified are well-established, relationships involving market factors, survival and dynamic capabilities are sparsely researched.

Research limitations/implications - The authors know more about the effects of firm specific factors and managerial socio cognitive attributes on operational and dynamic capabilities than we do the influence of market factors on either group of capabilities. Likewise, the authors know more about the influence of operational and dynamic capabilities on performance than we do their impact on precocity or survival.

Practical implications - As the pandemic has shown, businesses with adaptable capabilities (e.g. shifting from a brick and mortar to an online/omnichannel approach or micro-breweries competent to switch from manufacturing beer to hand sanitizer) have increased their chance of survival while helping society cope. Originality/value - This to the authors' knowledge is the first study to provide a comprehensive review of literature on the nebulous concept of capabilities, in the context of the burgeoning research stream on early internationalization.
\end{abstract}

Keywords International new ventures, Born globals, Dynamic capabilities, Systematic review, International entrepreneurship, Operational capabilities

Paper type Literature review

\section{Introduction}

We use a systematic approach to search, collate and synthesize extant literature on "capabilities developed for, during, or in response to internationalization or by international new ventures (INVs)" - an emerging theme per Jones et al. (2011, p. 637). The rapid growth of literature on born globals (BG) and international new ventures, and the paucity of reviews on the role of capabilities justify our study. To appreciate the contribution we seek to make, it is imperative to provide a synopsis of the nascent area of International Entrepreneurship

The authors are indebted to Professor Susan Freeman for constructive feedback on the earliest versions of the manuscript, to two anonymous reviewers for useful suggestions and to the Editor(s) for support and guidance in the review process.
Review of International Business and Strategy shing Limited 2059-6014 
(IE), the sub-domain to which the early, rapid and accelerated internationalization discourse belongs. It took 21 years (i.e. 1989-2009) for research in $I E$ to reach 323 studies (Jones et al., 2011), and just nine to double this tally (Baier-Fuentes et al., 2018; Bembom and Schwens, 2018; Servantie et al., 2016). For instance, Servantie et al. (2016) and Baier-Fuentes et al. (2018) identify 567 and 738 studies, respectively. Bembom and Schwens (2018) suggest the literature has reached 800 studies [1]. When a field begins to generate "knowledge products at a rate far outpacing our current capacity for recall, sense-making, and use" (Rousseau et al., 2008, p. 477), the need for a review becomes undeniable. As it reduces the production of fragmented knowledge and allows researchers to gauge scientific progress, evaluating accumulated research should take precedence over the pursuit of novelty (Oesterle and Wolf, 2011; Rousseau et al., 2008; Tranfield et al., 2003).

Past reviews comprise broad appraisals of IE (Baier-Fuentes et al., 2018; Jones et al., 2011; Coviello and Jones, 2004; Ji et al., 2019; Keupp and Gassmann, 2009; Knight and Liesch, 2016; Peiris et al., 2012; Servantie et al., 2016; Verbeke and Ciravegna, 2018), bibliometric reviews (Dzikowski, 2018; García-Lillo et al., 2017; Øyna and Alon, 2018; Rodríguez-Ruiz et al., 2019), integrative reviews of born globals and international new ventures exploring the first (Aspelund et al., 2007; Rialp et al., 2005a, 2005b) and second (Romanello and Chiarvesio, 2019) decades of research and critical reviews and conceptual articles dissecting terminology, definitions and thresholds (Cesinger et al., 2012; Coviello, 2015; Paul and Rosado-Serrano, 2019; Reuber et al., 2017; Svensson and Payan, 2009). Meanwhile, thematic or focused reviews assessing knowledge content (Covin and Miller, 2014; De Clercq et al., 2012; Mainela et al., 2014; Sedziniauskiene et al., 2019) have remained underrepresented. Indeed, knowledge on several constructs is still unstructured and fragmented (Jones et al., 2011; Keupp and Gassmann, 2009; Rodríguez-Ruiz et al., 2019).

Aside from two recent papers (Jie et al., 2021; Nguyen and Mort, 2020), there are no previous attempts to assess extant research on capabilities and early internationalization. This is surprising given that internationalization, by its very nature, is capabilities-based (Tallman and Fladmoe-Lindquist, 2002). The study of capabilities is fundamental for three reasons; capabilities are indispensable to entrepreneurial internationalization; they enable competitive strategy; and ultimately, enhance performance (Karra et al., 2008; Jones et al., 2011; Øyna and Alon, 2018; Sapienza et al., 2006). Capabilities engender some of the precocity inherent in early internationalization and help shed light on why young, small and sometimes resource-poor ventures, engage in the successful onward international expansion (Gabrielsson et al., 2008; Madsen and Servais, 1997; Sapienza et al., 2006; Weerawardena et al., 2007). The handful reviews and conceptual papers (Al-Aali and Teece, 2014; İpek, 2018; Øyna and Alon, 2018; Zahra et al., 2011) cover portions of the discourse. For instance, Øyna and Alon (2018) indicate capabilities are one of the preeminent thematic clusters on born global research. Likewise, İpek's (2018) assessment of the resource-based view (RBV) in internationalization underscores the significance of capabilities to RBV. Conceptual work by Al-Aali and Teece (2014) and Zahra et al. (2011) has laid the foundation for the application of a dynamic capabilities' perspective to early internationalization. Cavusgil and Knight (2015, p. 11), while reflecting on their award-winning article ponder: "What (other) organizational capabilities are salient to early internationalization and performance abroad?"

Cavusgil and Knight's (2005) contemplation is not isolated. Øyna and Alon (2018, p. 174) "suggest that some attention should be given to how the dependency of INVs/BGs on various capabilities develops and changes over time, and how they relate to other concepts investigated in other streams (e.g., global diversity, international intensity, and entrepreneurial orientation)." Thus, our problematization adopts neglect-spotting (Alvesson and Sandberg, 2011; Sandberg and Alvesson, 2011) to underline the lack of reviews on 
capabilities and early internationalization. Unlike Nguyen and Mort (2020), who use an integrative review of select articles to provide a microfoundations-based explanation on the role of capabilities in the internationalization of born globals, we use a systematic literature review to search, collate and synthesize extant literature on capabilities associated with born globals and international new ventures. Nguyen and Mort (2020) contribute to knowledge through an organizational framework and propositional inventories, whereas we pose the following questions: what capabilities are associated with born global (BGs) and INVs, what factors underpin capabilities and what outcomes are associated with capabilities? We distinguish our research from Jie et al. (2021), who focus on the capability-performance relationship - a subpart of our comprehensive review.

We identify eight operational (i.e. networking, entrepreneurial, marketing, knowledge and learning, innovation, financing, technology and management) and five higher-level (i.e. absorptive capacity, ambidexterity, dynamic managerial, dynamic learning and dynamic social) capabilities. Using content analysis and constant comparison, we draw three antecedents (i.e. firm specific factors, managerial socio cognitive attributes and market factors) and three outcomes (i.e. precocity, survival and performance), before linking these to operational and dynamic capabilities. We use synthesis by integration to demonstrate that just 7 of the 12 linkages are well-established. Concerning antecedents, we know more about the effects of firm specific factors and managerial socio cognitive attributes on operational and dynamic capabilities than we do the influence of market factors on either group of capabilities. Likewise, we know more about the influence of operational- and dynamic capabilities on performance than we do their impact on precocity or survival. Linkages involving market factors (i.e. as an antecedent), survival (i.e. as an outcome) and dynamic capabilities (i.e. both antecedent-capability and capability-outcome) are scantily researched.

To the nascent research stream in Review of International Business and Strategy (RIBS) examining the early and rapid internationalization of born globals and international new ventures (Alam et al., 2020; Coudounaris, 2018; Dow, 2017; Zalan, 2018), we contribute a capabilities-based perspective. Moreover, we add early internationalization to review papers published in RIBS (Coudounaris and Arvidsson, 2021; Dike and Rose, 2017; Gulanowski et al., 2018; Lopez-Morales, 2018; Thukral and Jain, 2021), which condense extant knowledge and set a future research agenda on internationalization. We are to the best of our knowledge, the first systematic review to provide taxonomy on capabilities pertinent to early internationalization, to synthesize extant knowledge on the antecedents (to) and outcomes of capabilities and to map directions for future research.

\section{Capabilities and early internationalization - contextualization}

The importance of understanding capabilities pertinent to early internationalization (Gabrielsson et al., 2008; Madsen and Servais, 1997; Sapienza et al., 2006; Weerawardena et al., 2007) stands in sharp contrast to the inadequate conceptualization and fragmentation evident in extant knowledge (Coviello, 2015; Jie et al., 2021; Nguyen and Mort, 2020). Coviello (2015) stresses that the interchangeable use of resources, capabilities and strategies obfuscates the discourse on entrepreneurial internationalization. It is imperative for IE research "to more clearly disentangle and then understand the relationships" among these elements (Coviello, 2015, p. 22). To plug this gap, we adopt a systematic literature review to search, code, organize and synthesize extant knowledge on capabilities and early internationalization.

The lack of a universal definition, which traces to the interpretation of the seminal studies (Oviatt and McDougall, 1994; Rennie, 1993), is so problematic that Svensson and Payan (2009) imply it may be emblematic of "academic protectionism" or "academic myopia." As multiple scholars (Madsen, 2013; Rialp et al., 2005a, 2005b; Zahra, 2005) have highlighted, much of 
subsequent research fails to use the four attributes of speed, scope, pace and degreelextent to conceptualize and operationalize early internationalization. Notwithstanding, the notion of generating measurable revenue from foreign sales early in the lifecycle of a venture (i.e. speeddegree), is the most unifying precept for both BG and INV research. Our conceptualization of "early internationalization," which is informed by Svensson and Payan (2009) includes both BG and INV research streams, and studies qualify for inclusion so long they depict a sizeable proportion of foreign revenue being earned at or near inception.

Like the research on early internationalization, inconsistencies in conceptualization typify the study of capabilities. Across International Business, Marketing and Management/ Strategy (Day, 1994; Knight and Kim, 2009; Leonard-Barton, 1992), Winter (2003) concerns regarding the lack of definitional clarity on capabilities linger. Winter (2003, p. 991) argues there is a "mystery surrounding both the terminology and the phenomenon." Several key studies (Collis, 1994; Day, 1994; Leonard-Barton, 1992; Teece et al., 1997; Winter, 2003) inform our conceptualization of capabilities, while Knight and Kim's (2009) definition of international business competence and Schmidt and Santamaria-Alvarez's (2021) recent paper on routines, provide parameters for the International Business context relevant for our review. This delineation of conceptual boundaries is fundamental in framing a review and serves as the backdrop to the search and screening procedures detailed below.

\section{Methodology}

Our systematic review embodies the tenets of scientific positivism and culminates in an audit trail (Briner et al., 2009; Reay et al., 2009; Rousseau et al., 2008; Tranfield et al., 2003). We approach the review with the objective of scoping (i.e. offering clarity by delineating and summarizing the literature on a key and unexplored area) (Armstrong et al., 2011; Peterson et al., 2017). This goal is especially appropriate "when a body of literature has not been extensively reviewed, or exhibits a large, complex, or heterogeneous nature" (Peters et al., 2015, p. 141). The previous overview alluded this point.

Figure 1 shows the Preferred Reporting Items for Systematic Reviews and Meta-Analyses model for this research. We used six combinations - [born global and capabilities], [global

Figure 1.

Preferred reporting items for systematic reviews and metaanalyses (PRISMA) framework

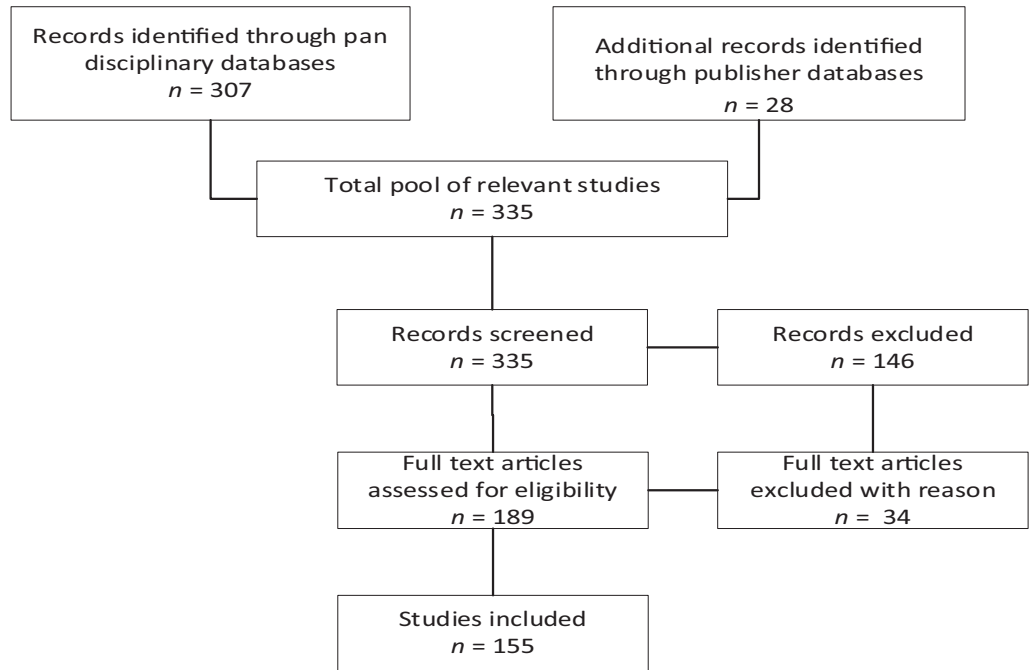


start up and capabilities], [international new venture and capabilities], [early internationalization and capabilities], [accelerated internationalization and capabilities] and [rapid internationalization and capabilities]. The search encompassed keywords, abstract and full text. Given the lack of past reviews on capabilities to serve as a starting point, the fact that the construct is inherently pan-disciplinary, and that hand-picked top journals may be susceptible to biases (Svensson, 2006; Svensson and Wood, 2006), we decided against searching by pre-selected journal.

Databases of ABI Inform, JSTOR and Science Direct produced 307 records. A search of publisher-specific databases (i.e. Blackwell-Wiley, Elsevier, Emerald, Palgrave, Sage, Springer and Taylor and Francis) yielded an additional 28 records resulting in a pool of 335 relevant studies. We excluded 146 records comprising book chapters, commentaries, conference papers, introductions to special issues and opinion pieces, reducing our sample to 189 full text journal articles.

Briner et al. (2009) and Reay et al. (2009) recommend determining a-priori, the inclusion criteria to guarantee the researcher is impartial and balanced. It is vital to ensure the guiding questions are specific but not too narrowly defined, and qualifying criteria are precise but not excessively stringent (Armstrong et al., 2011; MacLure, 2005). Criteria for inclusion were set as follows:

- The study examines the early internationalization of born globals or international new ventures and captures this using speed and degree.

- Capabilities are a focal construct.

- The study tests or theorizes a link between capabilities and another factor.

This reduced the sample by 34 studies. For instance, articles that recognize only the degree but not the speed (Jantunen et al., 2005) or vice-versa are excluded. The final sample which comprises 155 peer-reviewed journal articles published in English, compares to several recent studies (Coudounaris and Arvidsson, 2021; İpek, 2019; Kahiya, 2018; Mainela et al., 2014; Martineau and Pastoriza, 2016; Thukral and Jain, 2021).

We used a standard coding protocol for bibliometric aspects, research design and methodology (İpek, 2019; Kahiya, 2018; Tuomisalo and Leppäaho, 2018). Working independently, two coders transcribed data from the articles onto the coding sheets. Reliability was verified using inter-coder agreement and discussion and joint resolution ironed out disagreements. The results of the coding were carefully transcribed from a spreadsheet to a word document, ensuring accuracy and completeness. Appendices A and B serve as the source documents for the bibliometric and methodological attributes discussed below.

The synthesis of extant knowledge required an additional step. In line with Edmondson and McManus (2007), we contend that for an emerging research stream in which the literature comprises qualitative and quantitative research, a critical realist synthesis by integration is the most fitting technique (Rousseau et al., 2008; Torraco, 2005). We combine content analysis and constant comparison methods to delimit capabilities, identify antecedents (to) and outcomes of capabilities and assess the links between capabilities and the antecedents and outcomes. Our approach is compatible with two recent reviews (Kahiya, 2020; Martineau and Pastoriza, 2016) that use synthesis by integration.

\section{Findings}

\subsection{Profile of the studies}

The results first provide a bibliometric overview of the studies. A description of the methodological attributes follows thereafter.

Figure 2 shows the publishing trends over time. Zahra et al. (2000) are the foundational study on capabilities of born globals and international new ventures. While the first five
Review and synthesis 


\section{RIBS}

Figure 2.

Publishing trends over time

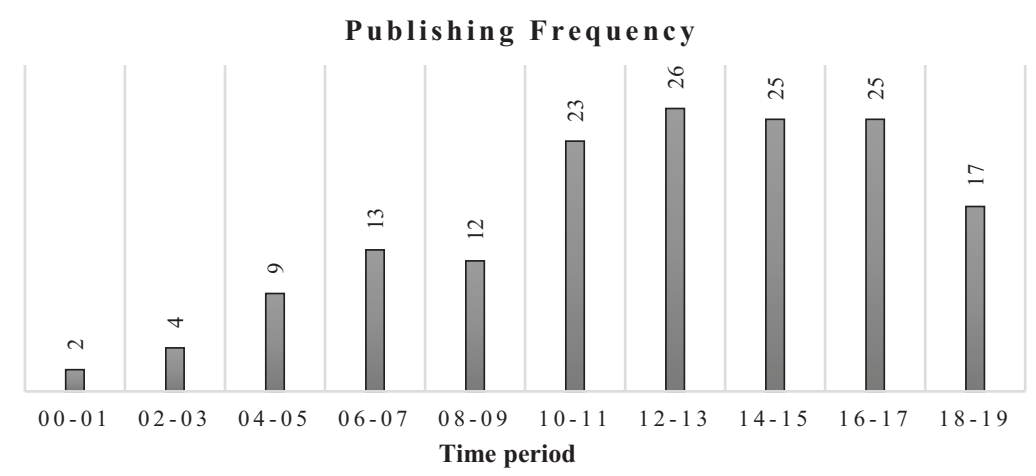

years were characterized by modest increments, research accelerated rapidly post-2006. By single year, the largest number of papers (i.e. 16) was recorded in 2012 and 2017, respectively. This is consistent with the reviews (Servantie et al., 2016), which underline a surge in research output in recent years.

Table 1 provides a list of journals that have published two or more articles on capabilities and early internationalization. The top 12 publications, which have disseminated four or more articles account for nearly two-thirds of this research. These journals are consistent with several recent reviews (Ipek, 2018; Kahiya, 2018; Li et al., 2017; Martineau and Pastoriza, 2016) on export- or internationalization-related topics. The journals cover three main disciplines - Entrepreneurship and small business, International Business and Marketing - indicating wide-ranging interest in the topic. There is rationale (ex post) for conducting a broad search. Had we used a pre-selected list, we would have missed articles published in some recognizable journals [e.g. Journal of the Academy of Marketing Science,

\begin{tabular}{llc}
\hline Publication & Abbreviation & Frequency \\
\hline Journal of International Entrepreneurship & JIE & 29 \\
International Business Review & IBR & 9 \\
Journal of World Business & JWB & 9 \\
International Entrepreneurship and Management Journal & IEMJ & 7 \\
International Small Business Journal & ISBJ & 7 \\
Journal of International Marketing & JIM & 7 \\
Management International Review & MIR & 7 \\
Industrial Marketing and Management & IMM & 6 \\
International Marketing Review & IMR & 6 \\
Entrepreneurship Theory and Practice & ETP & 4 \\
Journal of Business Research & JBR & 4 \\
Journal of International Business Studies & JIBS & 4 \\
Asian Business Management & ABM & 2 \\
European Business Review & EBR & 2 \\
Journal of Asia Business Studies & JABS & 2 \\
Journal of Promotion Management & JPM & 2 \\
Journal of Small Business Management & JSBM & 2 \\
Management Decision & MD & 2 \\
Qualitative Marketing Research & QMR & 2 \\
Review of International Business and Strategy & RIBS & 2 \\
\hline
\end{tabular}

Table 1.

Outlets for research on capabilities and born globals/ international new ventures 
Journal of Brand Management and Journal of Promotion Management] that are not typical mouthpieces for research on capabilities and early internationalization.

Table 2 depicts the 10 most cited studies per Google Scholar as of $13^{\text {th }}$ January 2020. We provide both the total citations and average citations per year. Zahra et al. (2000) are the most cited, followed by Knight and Cavusgil's (2004) award-winning paper. Also, of note is the work by Chetty and Campbell-Hunt (2004), another award-winning study in its own right [2]. 9 of the 10 studies appear on both lists but the order shifts to reflect the different speeds at which articles accumulate citations. Kuivalainen et al. (2007) join the top 10 ahead of Knight et al. (2004) while, perhaps, unsurprisingly, Knight and Cavusgil (2004) top the list based on average citations [3].

Data are drawn from 40 countries, but 12 of these (Figure 3) contribute four or more samples to the total pool of 161 . Cumulatively, they account for (115 of 161) $71 \%$ of the samples in this review. Small open economies (e.g. Denmark, New Zealand, Spain and Sweden) remain the focal point of this research stream, but there is interest in early internationalization, among both the traditional advanced (e.g. Germany and the USA) and big emerging economies (e.g. China and India).

Nearly a third (i.e. 52) of the studies specify the industry beyond designations of "service" or "manufacturing." Common descriptors encompass high tech (24), information and communication technology (9), software (9), biotech (5), medical technology (4) and designintensive (3) (Efrat and Shoham, 2012; Evangelista, 2005; Rodríguez-Serrano and MartínArmario, 2019; Thistoll and Pauleen, 2010; Tolstoy and Agndal, 2010; Weerawardena et al., 2019a; Zahra et al., 2003) suggesting a bias towards knowledge-intensive sectors.

\begin{tabular}{|c|c|c|c|c|c|c|}
\hline Ranking & Author(s) & $\begin{array}{c}\text { Total } \\
\text { citations }\end{array}$ & Ranking & Author(s) & $\begin{array}{l}\text { Citations } \\
\text { per year }\end{array}$ & \\
\hline 1 & Zahra et al. (2000) & 3,269 & 1 & Knight and Cavusgil (2004) & 202.1 & \\
\hline 2 & Knight and Cavusgil (2004) & 3,234 & 2 & Zahra et al. (2000) & 163.5 & \\
\hline 3 & Sapienza et al. (2006) & 1,425 & 3 & Sapienza et al. (2006) & 101.8 & \\
\hline 4 & Johanson and Vahlne (2003) & 1,415 & 4 & Johanson and Vahlne (2003) & 83.2 & \\
\hline 5 & Sharma and Blomstermo (2003) & 1,081 & 5 & Weerawardena et al. (2007) & 67.6 & \\
\hline 6 & Weerawardena et al. (2007) & 879 & 6 & Sharma and Blomstermo (2003) & 63.6 & \\
\hline 7 & Chetty and Campbell-Hunt (2004) & 866 & 7 & Chetty and Campbell-Hunt (2004) & 54.1 & \\
\hline 8 & Andersson and Wictor (2003) & 719 & 8 & Mort and Weerawardena (2006) & 46.4 & Table 2. \\
\hline 9 & Mort and Weerawardena (2006) & 650 & 9 & Andersson and Wictor (2003) & 42.3 & The 10 most cited \\
\hline 10 & Knight et al. (2004) & 526 & 10 & Kuivalainen et al. (2007) & 39.4 & studies \\
\hline
\end{tabular}

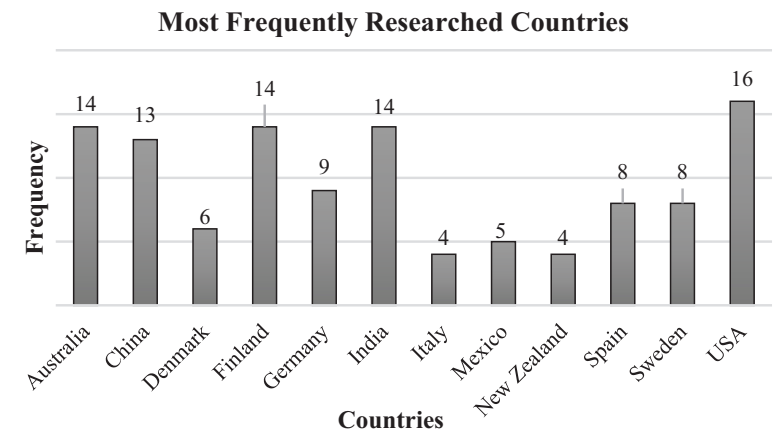

Figure 3. The most frequently surveyed countries 
Figure 4 provides a digest of the research design and methods, segmented into three principal strands - exploratory, descriptive and causal. The categories are not intended to be definitive and mutually exclusive; rather they indicate the main contours of the design and methodological landscape.

4.2.1 Exploratory research design. 23 studies (Al-Aali and Teece, 2014; Autio et al., 2011; Karra et al., 2008; Prashantham and Floyd, 2012; Weerawardena et al., 2019a; Zahra et al, 2011) adopt an exploratory research design. Within this cluster are two approaches monographs/research notes and conceptual articles. Written primarily as "provocations" monographs tend to feature in prominent journals. The conceptual articles combine an illustrative literature review and an instrumental case study. Often, they provide a synthesis and propositions.

4.2.2 Descriptive research design. 58 studies involve descriptive research design, and qualitative case studies (Evangelista, 2005; Evers et al., 2012; Freeman and Cavusgil, 2007; Laanti et al., 2007; Mort et al., 2012) constitute the majority (i.e. 49 out of 58). Nonprobability methods (e.g. purposive sampling) are the preferred approach for identifying cases. Uptake of a longitudinal approach through historical case analysis is higher among these studies compared to the exploratory or causal research design. Data reduction techniques (i.e. coding, pattern matching and explanation building) and cross-case comparisons are the most frequently used tools. We note here the underutilization of computer assisted textual analysis tools.

4.2.3 Causal research design. 74 studies (Baum et al., 2015; Cannone and Ughetto, 2014; Efrat and Shoham, 2012; Knight and Cavusgil, 2004; Kuivalainen et al., 2007; Martin and Javalgi, 2016; Rodríguez-Serrano and Martín-Armario, 2019; Weerawardena et al., 2015; Zahra et al., 2000), representing nearly half of the studies in our review, adopt causal research design. Mail surveys are the principal tool for collecting data, and secondary sources/databases are used sparingly. The use of electronic or online surveys is rare. 32 studies use basic multi-variate techniques, while the remainder use advanced multi-variate analytical methods. Ordinary least squares regression and structural equation modelling are the most regularly used basic and advanced multi-variate tools, respectively.

\subsection{Theories on capabilities and early internationalization}

4.3.1 Social capital perspective. Bourdieu's conceptualization of social capital has shaped social science research. According to Bourdieu and Wacquant (1992, p. 119), "social capital is the sum of the resources, actual or virtual, that accrue to an individual or a group by virtue

Figure 4 .

Research design and methods

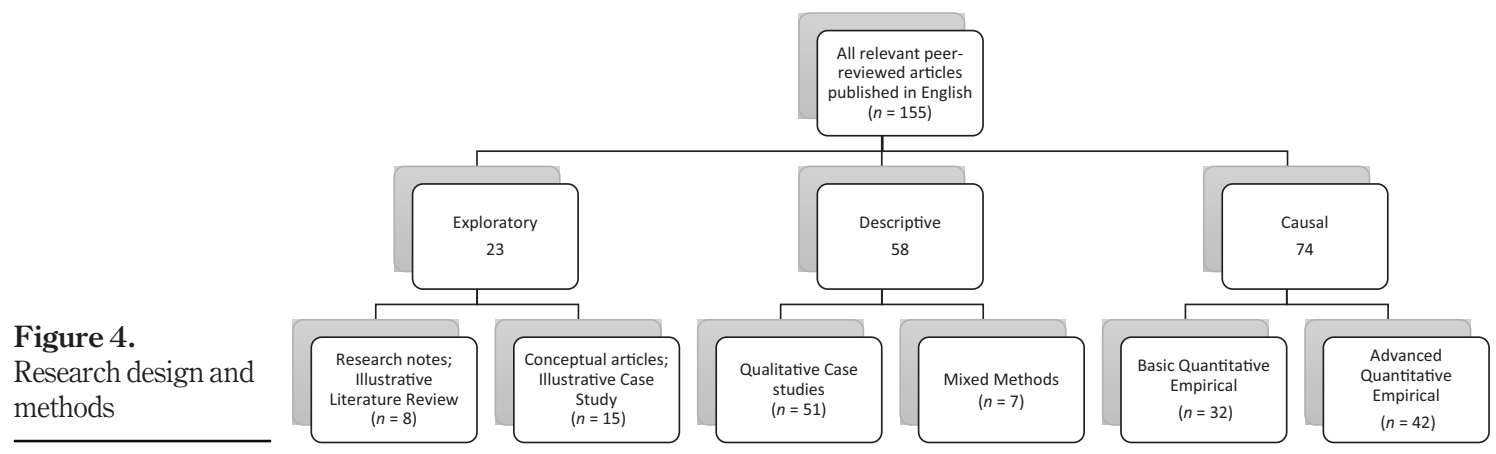


of possessing a durable network of more or less institutionalized relationships of mutual acquaintance and recognition." Uncovering the genesis of social capital, assessing its various manifestations and the impact on international expansion constitute recognizable research sub streams on internationalization (Chen and Lovvorn, 2011; Chetty and Agndal, 2007; Sinkovics et al., 2014). Studies that apply a social capital explanation for the role of capabilities in early internationalization embrace Kungwansupaphan and Siengthai (2014) and Manolova et al. (2010, 2014) and Prashantham and Dhanaraj (2010).

4.3.2 Knowledge perspective. Grant's (1996) dissertation on the organization as both a creator and repository of knowledge has helped promote the application of the knowledgebased view (KBV) in internationalization (Felin and Hesterly, 2007; Park et al., 2015; Prashantham, 2005). Because knowledge is the bedrock of internationalization, the KBV has found wide acceptance in this research stream. One application of the KBV to internationalization involves dissecting myriad knowledge-based components encompassing the know what, know why, know how, know who, know when (Park et al., 2015) and another focuses on the role of knowledge in facilitating internationalization (Nordman and Melén, 2008). This latter application is especially important to our study as it captures both the static and dynamic aspects of knowledge. For instance, several studies (Domurath and Patzelt, 2016; Park and Rhee, 2012; Rodríguez-Serrano and Martín-Armario, 2019), examining the effect of absorptive capacity on accelerated internationalization allude the KBV.

4.3.3 Learning perspective. Extending Levitt and March (1988, p. 319), who defined learning "as routine-based, history-dependent, and target-oriented," Huber (1991) identify manifold sources of learning including congenital, vicarious, experiential and grafting. Bruneel et al. (2010), De Clercq et al. (2012), Ipek (2019) and Pellegrino and McNaughton (2017) among others borrow from this foundational research to emphasize the application of the learning perspective to the internationalization of born globals international new ventures. For example, İpek (2019) underlines the explanatory power of organizational learning in export research, whereas De Clercq et al. (2012) and Pellegrino and McNaughton (2017) provide a detailed account of the evolution of learning in early and rapid internationalization. Examples of research applying the learning perspective to investigate capabilities and accelerated internationalization include Bruneel et al. (2010), De Clercq and Zhou (2014), Kim et al. (2011) and Voudouris et al. (2011).

4.3.4 Resource-based view. While Barney's (2001) valuable - rare - inimitable - nonsubstitutable typology is arguably the most recognizable framework on the RBV, the perspective traces to earlier scholarship on the theory of the firm (Snow and Hrebiniak, 1980; Wernerfelt, 1984). Leonard-Barton (1992) elaborates that the study of capabilities originates from the research stream on competences, invisible assets and resource deployments, conducted under the auspices of the RBV. The application of the RBV to the study of internationalization can be summed up as follows: The presence of an ample resource base may motivate the development of capabilities, and the routinization of those capabilities fosters new resources (İpek, 2018; Pinho and Prange, 2016). Tenets of the RBV are evident in some studies encompassing Sepulveda and Gabrielsson (2013), Tolstoy and Agndal (2010), Verreynne et al. (2016) and Zahra et al. (2003).

4.3.5 Institutional perspective. The institutional perspective is an established lens in both Management and International Business. Most of the research on institutional theory and internationalization (Gaur et al., 2014; Kostova et al., 2008; Kiss and Danis, 2008), emanates from North's (1990) dissertation. Broadly, the institutional environment facilitates or constrains internationalization. The institutional environment can influence the development of capabilities and moderate the relationship between those capabilities and outcomes of internationalization. Surprisingly, only Zhang et al. (2017) incorporate an 
institutional perspective to probe the role of sub-national institutions in capability development. Institutions are underappreciated in early internationalization and nearly 30 years after Oviatt and McDougall, scholarship is still answering the elementary question of what institutional attributes promote the emergence of born globals (Fainshmidt $e t$ al., 2021; Prieto-Sánchez and Merino, 2021).

4.3.6 Microfoundations. While the microfoundations perspective is not novel (Collins, 1981) it is an increasingly pivotal lens in Management, Organizational Behaviour and Strategy (Barney and Felin, 2013; Felin et al., 2012, 2015; Minniti and Bygrave, 1999; Teece, 2007). Of relevance to our review is its application to entrepreneurship, dynamic capabilities and firm internationalization (Minniti and Bygrave,1999; Teece, 2007). Teece (2007) expostulates that microfoundations serves as a mechanism for delayering individuals, processes and structure embedded in capabilities, competencies and routines. Yet, Prashantham and colleagues (Prashantham and Floyd, 2012, 2019) are among the few scholars who use microfoundations to the study of capabilities and early internationalization.

\section{Synthesis and discussion}

To reiterate, our synthesis distinguishes operational from dynamic capabilities, identifies three antecedents (firm specific factors, managerial socio cognitive attributes and market factors) and three outcomes (precocity, survival and performance) of the capabilities, before dissecting the resultant linkages. We begin this by delimiting capabilities. This is followed by an outline of correlates and a discussion of the linkages.

\subsection{Delimiting capabilities}

Operational "functional," "ordinary," "survivalist" "threshold" or "zero-order" capabilities are static competences a firm requires on a day-to-day basis, whereas dynamic capabilities are higher level competences which confer competitive advantage. We delineate 13 capabilities and their illustrative definitions. Because many of the studies do not offer lucid definitions, we extended our search to mainstream Management literature. Definitions for "entrepreneurial," "financing," "innovation," "networking" and "absorptive capacity" are drawn from the literature being studied, while the remainder are sourced from broader Management literature. Table 3 offers a summary of illustrative definitions of the capabilities, indicative components and select past literature.

\subsection{Antecedents to capabilities}

There are three main clusters of antecedents - firm specific factors, managerial socio cognitive attributes and market factors. Within each of these clusters, we highlight the specific variables studied. The clusters are comparable to groupings found in recent reviews of IE research (İpek, 2019; Kahiya, 2020; Martineau and Pastoriza, 2016). For instance, Kahiya (2020) identifies managerial, environmental and firm-level determinants, while Martineau and Pastoriza (2016) recognize firm-level, individual-level and environmental antecedents.

\subsection{Outcomes of capabilities}

Precocity, survival and performance are the three primary outcomes of capabilities. Precocity -sometimes referred to as early international orientation or proclivity - is the tendency to develop the aptitude to internationalize earlier than anticipated. Survival, or business longevity pertains to how well a venture sustains its operations post initial market entry. The concept of survival or longevity is especially central to the early 


\begin{tabular}{|c|c|c|c|c|}
\hline Capability & Definition & Components & Illustrative studies & \\
\hline Entrepreneurial & $\begin{array}{l}\text { "... the ability to identify } \\
\text { and acquire the necessary } \\
\text { resources to act upon } \\
\text { opportunities identified in } \\
\text { the market, or to create new } \\
\text { market opportunities" } \\
\text { (Karra et al., 2008, p. 443) }\end{array}$ & $\begin{array}{l}\text { Bricolage, collaboration, } \\
\text { institutional bridging, } \\
\text { opportunity identification }\end{array}$ & $\begin{array}{l}\text { (Freeman and Cavusgil, 2007; } \\
\text { Falahat et al,, 2018; } \\
\text { Gerschewski et al., 2016; } \\
\text { Hughes et al., 2010; Odorici } \\
\text { and Presutti, 2013; } \\
\text { Romanello and Chiarvesio, } \\
\text { 2017; Zhang et al., 2017; Zhou } \\
\text { et al., 2010) }\end{array}$ & \\
\hline Financing & $\begin{array}{l}\text { Building and leveraging a } \\
\text { strong venture financing } \\
\text { network (Manolova et al., } \\
\text { 2014) }\end{array}$ & $\begin{array}{l}\text { Internal/external-, short/ } \\
\text { long term-, access (to) } \\
\text { financing }\end{array}$ & $\begin{array}{l}\text { (Gabrielsson et al., 2004; } \\
\text { Huang and Hsieh, 2013; } \\
\text { Kuivalainen } \text { et al., 2010) }\end{array}$ & \\
\hline Innovation & $\begin{array}{l}\text { "The precocity, receptivity, } \\
\text { and inclination to adopt } \\
\text { unfamiliar ways and } \\
\text { ideas... (for) meeting } \\
\text { customer needs or creating } \\
\text { new offerings" (Kim et al., } \\
\text { 2011, p. 881) }\end{array}$ & $\begin{array}{l}\text { Business model, product, } \\
\text { process, technological }\end{array}$ & $\begin{array}{l}\text { (Abrahamsson et al., 2019; } \\
\text { Cannone and Ughetto, 2014; } \\
\text { Spence et al., 2011; Thai and } \\
\text { Chong, 2008; Thistoll and } \\
\text { Pauleen, 2010; } \\
\text { Weerawardena et al., 2015) }\end{array}$ & \\
\hline $\begin{array}{l}\text { Learning and } \\
\text { knowledge } \\
\text { acquisition }\end{array}$ & $\begin{array}{l}\text { “... we may think of } \\
\text { learning in an iterated- } \\
\text { choice context, as the } \\
\text { process of updating the } \\
\text { probabilities of choosing } \\
\text { any particular action as new } \\
\text { information on its } \\
\text { consequences is received" } \\
\text { (Minniti and Bygrave, 2001, } \\
\text { p. 8) }\end{array}$ & $\begin{array}{l}\text { Acquiring, disseminating, } \\
\text { integrating, "unlearning," } \\
\text { "relearning" }\end{array}$ & $\begin{array}{l}\text { (Baum et al., 2011; Chetty } \\
\text { and Campbell-Hunt, 2004; } \\
\text { De Clercq and Zhou, 2014; } \\
\text { Kumar, 2013; Varma et al., } \\
\text { 2016; Voudouris } \text { et al., 2011; } \\
\text { Weerawardena } \text { et al., 2007; } \\
\text { Zahra et al., 2011) }\end{array}$ & \\
\hline Management & $\begin{array}{l}\text { "... the management } \\
\text { capacity, management } \\
\text { expertise, and management } \\
\text { processes available to the } \\
\text { firm for evaluating, } \\
\text { shedding, adding, bundling, } \\
\text { and leveraging its resources } \\
\text { to achieve a competitive } \\
\text { advantage" (Graves and } \\
\text { Thomas, 2006, p. 208) }\end{array}$ & $\begin{array}{l}\text { Planning, organizing, } \\
\text { leading, decision-making }\end{array}$ & $\begin{array}{l}\text { (Boermans and Roelfsema, } \\
\text { 2013; Cannone and Ughetto, } \\
\text { 2014; Efrat and Shoham, } \\
\text { 2012; Gabrielsson } \text { et al., } \\
\text { 2004; Kungwansupaphan } \\
\text { and Siengthai, 2014; } \\
\text { Nummela at al., 2016) }\end{array}$ & \\
\hline Marketing & $\begin{array}{l}\text { There are two strands; } \\
\text { capabilities pertaining to } \\
\text { the marketing mix, and } \\
\text { those concerning the } \\
\text { development and } \\
\text { deployment of marketing } \\
\text { strategy (Morgan } \text { et al., } \\
\text { 2009) }\end{array}$ & $\begin{array}{l}\text { Branding, customer } \\
\text { support, entrepreneurial } \\
\text { marketing }\end{array}$ & $\begin{array}{l}\text { (Altshuler and } \\
\text { Tarnovskaya, 2010; } \\
\text { Cannone and Ughetto, 2014; } \\
\text { Efrat and Shoham, 2012; } \\
\text { Haskell et al., 2016; Khavul } \\
\text { et al., 2010; Kim et al., 2011; } \\
\text { Knight et al., 2004; Laudien } \\
\text { and Daxböck, 2017; Martin } \\
\text { et al., 2018; Mort et al., 2012) }\end{array}$ & \\
\hline Networking & $\begin{array}{l}\text { “... the capacity of the firm } \\
\text { to develop a purposeful set } \\
\text { of routines within its } \\
\text { networks, resulting in the }\end{array}$ & $\begin{array}{l}\text { Building, adding, deleting, } \\
\text { reconfiguring }\end{array}$ & $\begin{array}{l}\text { (Chetty and Campbell-Hunt, } \\
\text { 2004; Debrulle and Maes, } \\
\text { 2015; Falahat et al., 2018; } \\
\text { Hughes et al., 2019; } \\
\qquad \text { (continued) }\end{array}$ & $\begin{array}{r}\text { Table 3. } \\
\text { Capabilities - } \\
\text { definitions, } \\
\text { components and } \\
\text { indicative studies }\end{array}$ \\
\hline
\end{tabular}




\section{RIBS}

\begin{tabular}{|c|c|c|c|}
\hline Capability & Definition & Components & Illustrative studies \\
\hline & $\begin{array}{l}\text { generation of new resource } \\
\text { configurations and the } \\
\text { firm's capacity to integrate, } \\
\text { reconfigure, gain and } \\
\text { release resource } \\
\text { combinations" (Mort and } \\
\text { Weerawardena, 2006, } \\
\text { p. 558) }\end{array}$ & & $\begin{array}{l}\text { Prashantham and Dhanaraj, } \\
\text { 2010; Prashantham et al., } \\
\text { 2019; Tolstoy and Agndal, } \\
\text { 2010) }\end{array}$ \\
\hline Technological & $\begin{array}{l}\text { “... include the technology } \\
\text { skills of the individuals and } \\
\text { teams, the processes and } \\
\text { routines followed, and other } \\
\text { technological assets (e.g., } \\
\text { machines or information } \\
\text { and manufacturing } \\
\text { systems) that together } \\
\text { contribute to the firm's } \\
\text { path-dependent technology } \\
\text { potential" (Kyläheiko et al., } \\
\text { 2011, p. 511) }\end{array}$ & $\begin{array}{l}\text { Patent, copyright, } \\
\text { trademark, trade secrets, } \\
\text { technical expertise, ICT, } \\
\text { unique processes, } \\
\text { certifications }\end{array}$ & $\begin{array}{l}\text { (Falay et al., 2007; } \\
\text { Gabrielsson et al., 2004; } \\
\text { Haskell et al., 2016; Efrat } \\
\text { and Shoham, 2012; Kim } \\
\text { et al., 2011; Knight and } \\
\text { Cavusgil, 2004, 2005; Zhang } \\
\text { et al., 2013) }\end{array}$ \\
\hline $\begin{array}{l}\text { Absorptive } \\
\text { capacity }\end{array}$ & $\begin{array}{l}\text { "... a dynamic capability } \\
\text { pertaining to knowledge } \\
\text { creation and utilization that } \\
\text { enhances a firm's ability to } \\
\text { gain and sustain a } \\
\text { competitive advantage" } \\
\text { (Zahra and George, 2002, } \\
\text { p. 185) }\end{array}$ & $\begin{array}{l}\text { Acquisition, assimilation, } \\
\text { transformation and } \\
\text { exploitation }\end{array}$ & $\begin{array}{l}\text { (Altshuler and } \\
\text { Tarnovskaya, 2010; } \\
\text { Domurath and Patzelt, 2016; } \\
\text { Freeman et al., 2010; Park } \\
\text { and Rhee, 2012; Rodríguez- } \\
\text { Serrano and Martín- } \\
\text { Armario, 2019) }\end{array}$ \\
\hline Ambidexterity & $\begin{array}{l}\text { "... a dynamic capability } \\
\text { (which) embodies a complex } \\
\text { set of routines including } \\
\text { decentralization, } \\
\text { differentiation, targeted } \\
\text { integration, and the ability } \\
\text { of senior leadership to } \\
\text { orchestrate the complex } \\
\text { trade-offs that } \\
\text { ambidexterity requires" } \\
\text { (O'Reilly and Tushman, } \\
\text { 2008, p. 2000) }\end{array}$ & $\begin{array}{l}\text { Effectual-causal logics, } \\
\text { exploration-exploitation, } \\
\text { proactive-reactive, profit- } \\
\text { growth focus, } \\
\text { customization-adaptation }\end{array}$ & $\begin{array}{l}\text { (Han and Celly, 2008; } \\
\text { Jantunen et al., 2008; } \\
\text { Monferrer et al., 2015) }\end{array}$ \\
\hline $\begin{array}{l}\text { Dynamic } \\
\text { managerial }\end{array}$ & $\begin{array}{l}\text { "... the capabilities with } \\
\text { which managers build, } \\
\text { integrate, and reconfigure } \\
\text { organizational resources } \\
\text { and competences. . .they } \\
\text { reflect three underlying } \\
\text { factors: managerial human } \\
\text { capital, managerial social } \\
\text { capital, and managerial } \\
\text { cognition" (Adner and } \\
\text { Helfat, 2003, p. 1020) }\end{array}$ & $\begin{array}{l}\text { Alertness, cognition, } \\
\text { dexterity, percipience, } \\
\text { sensemaking }\end{array}$ & $\begin{array}{l}\text { (Autio et al., 2011; De Clercq } \\
\text { and Zhou, 2014; Oxtorp, } \\
\text { 2014; Rasmussan et al., } \\
\text { 2001) }\end{array}$ \\
\hline
\end{tabular}




\begin{tabular}{|c|c|c|c|}
\hline Capability & Definition & Components & Illustrative studies \\
\hline $\begin{array}{l}\text { Dynamic } \\
\text { learning }\end{array}$ & $\begin{array}{l}\text { “... involve coordination, } \\
\text { learning, and strategic } \\
\text { competitive response } \\
\text { activities that include new } \\
\text { creatively and innovatively } \\
\text { derived routines and } \\
\text { resources" (Verreynne } \text { et al., } \\
\text { 2016, p. 4288) }\end{array}$ & $\begin{array}{l}\text { Low repetition patterning, } \\
\text { change intent, resource } \\
\text { sustainability, path } \\
\text { breaking }\end{array}$ & $\begin{array}{l}\text { (Bruneel } \text { et al., 2010; } \\
\text { Schwens and Kabst, 2011; } \\
\text { Prashantham and Dhanaraj, } \\
\text { 2010; Voudouris et al., 2011) }\end{array}$ \\
\hline $\begin{array}{l}\text { Dynamic social } \\
\text { capital }\end{array}$ & $\begin{array}{l}\text { The capacity to renew, } \\
\text { regenerate and reconfigure } \\
\text { (initial) social capital in } \\
\text { response to ties } \\
\text { obsolescence and tie decay } \\
\text { (Prashantham and } \\
\text { Dhanaraj, 2010) }\end{array}$ & $\begin{array}{l}\text { Initial social capital, tie } \\
\text { obsolescence, tie decay }\end{array}$ & $\begin{array}{l}\text { (Loufrani-Fedida et al., 2019; } \\
\text { Schwens and Kabst, 2011; } \\
\text { Voudouris et al., 2011) }\end{array}$ \\
\hline
\end{tabular}

Review and synthesis

\subsection{Well-established research linkages}

5.4.1 Firm specific attributes and operational capabilities, linkage 1a-2d $(n=27)$. There is wide-ranging support for the positive influence of firm specific attributes on operational capabilities. Entrepreneurial orientation drives global technology competences and information technology capabilities; it fosters networking capabilities; and in combination with pre-existing knowledge, it enables marketing and service capabilities (Falahat et al., 2015; Knight and

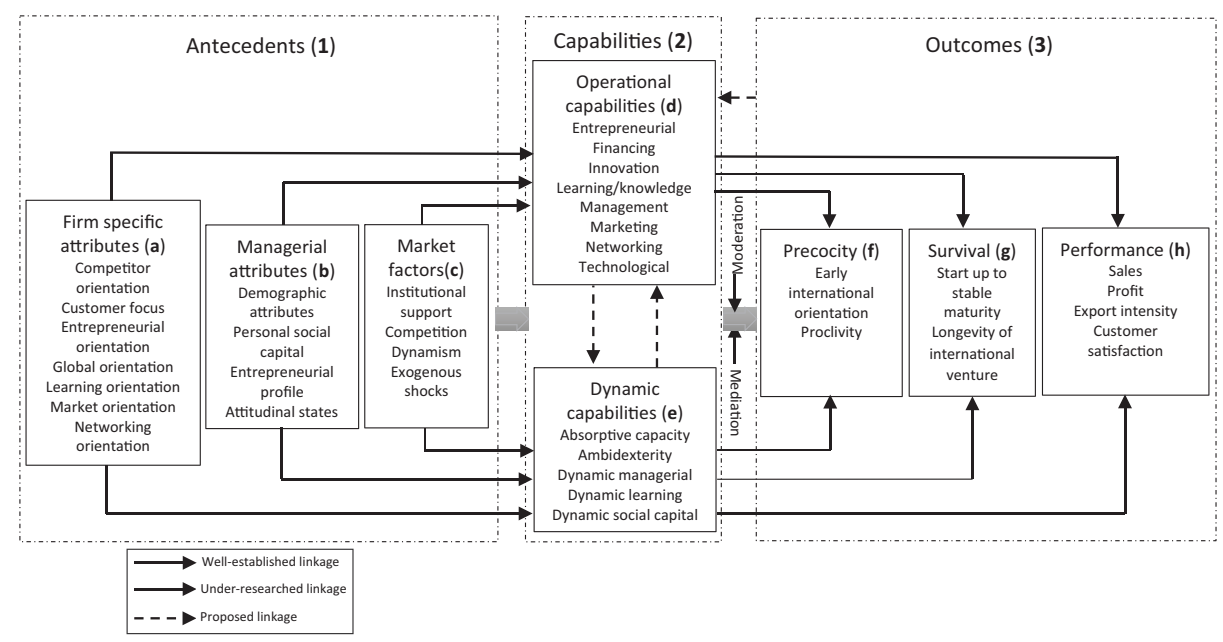

Figure 5.

Antecedents and outcomes of capabilities 
Cavusgil, 2004; Martin and Javalgi, 2019; Martin and Javalgi, 2016; Martin et al., 2018; Zhang et al., 2013). Likewise, alliance entrepreneurship - a construct conceptually analogous to entrepreneurial orientation - influences alliance capability (i.e. an operational capability akin to networking). Further, market orientation and customer focus are critical for the development of both marketing and technological capabilities (Karatepe et al., 2016; Kim et al., 2011; Knight and Cavusgil, 2004; Yu et al., 2011; Zhang et al., 2013). Often these technological competences manifest in the form of innovations. Global-, learning- and competitor orientation(s) are represented to a lesser extent. Global orientation enables marketing capabilities; coopetition empowers innovative capabilities; while learning orientation helps nurture IT-related technological capabilities (Freeman and Cavusgil, 2007; Vapola et al., 2008; Zhang et al., 2013).

5.4.2 Firm specific attributes and dynamic capabilities, linkage $1 a-2 e(n=13)$. Strategic orientations are a key predictor of dynamic capabilities. Entrepreneurial- and market orientation explain absorptive capacity, and international orientation influences dynamic learning capabilities (Monferrer et al., 2015; Rodríguez-Serrano and Martín-Velicia, 2015; Rodríguez-Serrano and Martín-Armario, 2019; Voudouris et al., 2011; Weerawardena et al., 2015; Zhou et al., 2010). The function pre-existing knowledge and resources play in fostering dynamic capabilities appears more widespread than in the case of operational capabilities (Pehrsson et al., 2015; Prashantham and Dhanaraj, 2010; Tolstoy and Agndal, 2010). For instance, locally acquired knowledge resources and knowledge fostered through headquarters and subsidiary interactions help cultivate dynamic and resource combination capabilities. Likewise, dynamic social capital emanates from using firm attributes (e.g. experience and links with multi-national companies) to leverage initial social capital.

5.4.3 Managerial socio cognitive attributes and operational capabilities, linkage 1b-2d $(n=17)$. The premise of this linkage is that entrepreneurial profiles spawn divergent operational capabilities. Because managerial or owner attributes (e.g. education, experience, expertise, language proficiency and mindset) embody an individual's social capital, managerial socio cognitive attributes explain marketing and networking capabilities (Falay et al., 2007; Freeman and Cavusgil, 2007; Gabrielsson et al., 2004; Kungwansupaphan and Siengthai, 2014; Odorici and Presutti, 2013; Rasmussan et al., 2001; Tang, 2006). An inverse relationship between operational capabilities and managerial socio cognitive attributes is plausible. For instance, that managerial capabilities influence entrepreneurial orientation is explained by the fact that decision makers can orchestrate the requisite strategic posture.

5.4.4 Managerial socio cognitive attributes and dynamic capabilities, linkage $1 b$-2e $(n=$ 10). Individual-experiential attributes associated with managerial profiles are the well-spring of dynamic capabilities (Evers, 2011; Fletcher and Prashantham, 2011; Freeman et al., 2010; Huang and Hsieh, 2013; Mort and Weerawardena, 2006; Oxtorp, 2014; Prashantham and Dhanaraj, 2010; Prashantham and Floyd, 2012, 2019; Voudouris et al., 2011). Among other attributes, managers should be adept at anticipating the precise point at which tie decay renders static social capital obsolete, activating the cycle of renewal, growth or upgrading. Admittedly this demands of managers, high core self-evaluation and a reflective mindset. The transient nature of managerial socio cognitive attributes helps explain the differing speeds with which dynamic capabilities are developed, as well as the potency when deployed. For instance, return migration, indigenous knowledge and collaborative decision-making foster managerial socio cognitive resources which influence different forms of dynamic capabilities.

5.4.5 Operational capabilities and precocity, $2 d-3 f(n=47)$. The bulk of these studies (Bruneel et al., 2010; Evangelista, 2005; Falay et al., 2007; Freeman and Cavusgil, 2007; GarcíaCabrera et al., 2017; Kraus et al., 2017; Yu et al., 2011) examine drivers of precocity or proclivity through a comparison of born globals/international new ventures to other internationalizing firms or traditional exporters. To the extent that they enable an internationalizing firm to invest 
in the innovations vital for early internationalization, technological capabilities increase the propensity to be a born global or international new venture. As they enable a venture to adapt communication, engagement and customer support to different markets, marketing capabilities facilitate accelerated internationalization and rapid acceptance in overseas markets. This linkage also holds for financing capabilities, knowledge competences and organizational flexibility.

5.4.6 Operational capabilities and performance, $2 d-3 h(n=23)$. Marketing, service and customer-based competences inspire performance and growth in born globals (Efrat and Shoham, 2012; Karatepe et al., 2016; Kumar and Yakhlef, 2014; Martin and Javalgi, 2016, 2019; Martin et al., 2018). The effectiveness of marketing capabilities emanates from their capacity to confer competitive and positional advantages on the internationalizing firms. To varying degrees, entrepreneurial, management, networking and technological competences (Khalid and Larimo, 2012; Kocak and Abimbola, 2009; Knight and Cavusgil, 2004; Zhang et al., 2013) also influence performance. Entrepreneurial and technological capabilities stimulate operational and financial performance, whereas management capabilities are critical for growth.

5.4.7 Dynamic capabilities and performance, 2e-3h $(n=10)$. This cluster (Chin et al., 2016; Han and Celly, 2008; Hughes et al., 2010; Pehrsson et al., 2015; Prashantham et al., 2019; Rodríguez-Serrano and Martín-Armario, 2019; Rodríguez-Serrano and Martín-Velicia, 2015; Weerawardena et al., 2015) investigates absorptive capacity, dynamic learning capabilities and ambidexterity. Absorptive capacity accounts for the bulk of the variability in innovation performance among early and rapidly internationalizing firms. Additional benefits accrue through a reverse linkage in that knowledge acquisition and absorptive capabilities developed through rapid internationalization may drive superior performance in the domestic market. Network capability upgrading, dynamic learning capabilities and ambidexterity also influence performance although the precise mechanisms by which this occurs is not always evident in the literature.

\subsection{Under-researched linkages}

5.5.1 Market factors and operational capabilities, linkage $1 c-2 d(n=3)$. The three studies (Laurell et al., 2017; Zhang et al., 2013; Zhang et al., 2017) make this one of the most sparsely researched linkages. While the positive impact of government support and research institutions on the development of operational capabilities may transcend countries, the influence of legal rules and government transparency on capability growth is contextbound. This indicates an institutional or context-embedded explanation is useful for unpacking the link between market factors and operational capabilities.

5.5.2 Market factors and dynamic capabilities, linkage $1 c-2 e(n=5)$. Five studies (Evers et al., 2012; Huang and Hsieh, 2013; Prashantham and Floyd, 2012; Oxtorp, 2014; Voudouris et al., 2011) test the relationship between market factors and dynamic capabilities. Environmental turbulence, shifts in demands, changing customer preferences, competition and crises engender "repeated exposure to situational uncertainty" necessary for activating the single and double loop learning vital for fostering incremental, renewal and regenerative dynamic marketing capabilities [4].

5.5.3 Operational capabilities and survival, $2 d-3 g(n=4)$. A small cluster (Efrat and Shoham, 2012; Gabrielsson and Gabrielsson, 2013; Kumar and Yakhlef, 2014; Nummela et al., 2016) evaluates the linkage between operational capabilities and survival. Management and innovation capabilities are vital for long term survival, and shortfalls in managerial capabilities expedite venture failure. The efficacy of managerial capabilities on survival arises from their capacity to resolve growth-related problems which often plague early internationalizing firms.
Review and synthesis 
5.5.4 Dynamic capabilities and precocity, $2 e-3 f(n=4)$. Al-Aali and Teece (2014), Andersson and Evers (2015), Lin and Si (2019), Loufrani-Fedida et al. (2019) and Sapienza et al. (2006) contribute to the linkage between dynamic capabilities and precocity. Dynamic capabilities have complementary roles in stimulating precocity. For instance, dynamic managerial capabilities underpin opportunity identification - a fundamental component of early internationalization; and ambidexterity (i.e. a trade-off between exploration and exploitation) determines how early and quickly the opportunities identified are targeted. Because dynamic networking capabilities are a multi-layered reservoir of relational competences, they operationalize precocity and enable early internationalizing ventures to commence, sustain and expand international operations. Interestingly, a reverse causal relationship is possible in that early internationalization may spark the development of dynamic capabilities required for survival and growth.

5.5.5 Dynamic capabilities and survival, $2 e-3 g(n=2)$. The two studies (Sapienza et al., 2006; Zettinig and Benson-Rea, 2008) outlining the connection between dynamic capabilities and survival make this the least researched linkage. Zettinig and Benson-Rea (2008) illustrate that adaptability on the fly is the key to longevity for early internationalization, while Sapienza et al. (2006) argue that the dynamic capabilities required for survival diverge from those necessary for growth. For example, survival is associated with the reconfiguring of costly market-facing capabilities, whereas growth pertains to the less expensive and more pliable internal capabilities.

\subsection{Proposed linkages}

5.6.1 Relationship between dynamic and operational capabilities, 2d-2e. What capabilities does a venture use the day international operations commence? "Operational followed by dynamic" is one premise: In this instance, capability upgrading and resource combination help harness and reconfigure operational capabilities into a dynamic form. Another view is that dynamic capabilities are the baseline at the dawn of internationalization. Venture formation manifests in translating dynamic capabilities to the deployable operational version. Regardless of the exact starting point, the shift from "dynamic to operational" or "operational to dynamic" culminates in crossing the chasm, which behaves scholarship to recognize the microprocesses associated with the routinization of the transformed or upgraded competences.

5.6.2 Reverse relationship between outcomes and capabilities. Another potentially informative line of inquiry is the reverse connection between outcomes of early internationalization and capabilities. It is reasonable to infer that sustained financial and operational performance may obviate the need to develop or upgrade capabilities. Thus, one can theorize that periods of sustained growth or performance diminish the likelihood of capability reconfiguration, renewal, or upgrading. Correspondingly, stagnation in growth or underperformance increases such probability. We reiterate these arguments as we suggest directions for future scholarship.

\section{Directions for future research}

In charting directions for subsequent studies, we focus on research context, knowledge content and implications for theory and practice and underline manifold areas later studies should address. Our approach is consistent with De Clercq et al. (2012), İpek (2019), Kahiya (2018) and Tuomisalo and Leppäaho (2018).

\subsection{Contexts}

The focus on developed markets and the pivot towards the international activities of knowledge-intensive ventures makes this research stream inadvertently "context free" (i.e. seeks to produce universal knowledge from empirical generalizations, while neglecting nuance associated with contextual dissimilarities) (Tsui, 2004). We advocate a shift from 
context-excluded research to context-sensitive and context-embedded research (Michailova, 2011; Tsui, 2007).

Concerning the national context, we recommend additional context-sensitive and new contextembedded research. The underrepresentation of the role of capabilities in the international exploits of firms from Sub Saharan Africa (SSA) and Central and Eastern Europe (CEE) (e.g. the 60-plus countries constituting SSA and CEE contribute just three studies) probably deprives extant research of potentially enriching insights. Indeed, scholars (Vissak, 2007) studying CEEbased firms note the prevalence of "fast internationalizers" in that region. Few studies address comparative entrepreneurial internationalization. The small cluster of comparative studies matches firms in geographically and culturally proximate markets, an approach which robs theory of contrastive explanations. Instead of another comparative study focusing on knowledgeintensive firms in small open economies, $\mathbb{E}$ research will prosper from, for instance, comparing generic manufacturing BGs from Tunisia, to newly listed ventures in Europe, or telematics software providers in New Zealand [5]. Likewise, examining capabilities outside the confines of knowledge-intensive firms is potentially edifying, as it may alter the prominence of some capabilities (e.g. technology and innovation). Studying these diverse contexts will test the limits of our knowledge (i.e. falsification or verification) - a crucial precursor to theoretical advancements and adaptation of strategy (Khanna, 2014). This also provides the pluralism so desperately required to move an emerging discipline forward (Tsui, 2007).

\subsection{Capabilities construct and correlates}

There is limited use of formal definitions for the countless capabilities researched. We advocate the adoption of the illustrative definitions and components of capabilities provided in Table 3 to disentangle capabilities from one another and from related constructs. A portion of the literature makes hyperbolic claims about dynamic capabilities epitomized by the statement "this study uses a dynamic capabilities perspective." Such declarations alone do not qualify a study as dynamic capabilities-focused, much less help throw light on many areas of debate. We recommend a conceptualization of dynamic capabilities involving attributes like change, microprocesses, liminality, routinization, among others. If, as Autio et al. (2011) argue, every capability comprises two parameters - "organizing process" and "cognitive map" - then IE scholarship is merely scratching the surface.

We also encourage the examination of other capabilities beyond those covered in this stream of research. For instance, organizational entrainment (Khavul et al., 2010) - the ability of a rapidly internationalizing firm to synchronize its activity cycles with those of key exchange partners - fits the profile of a higher-level or dynamic capability. Beyond IE there is growing interest (Parker and Ameen, 2018) in studying resilience as a capability.

Subsequent studies should focus on two under-researched linkages (i.e. $1 c-2 d$ and $1 c-2 e$ ) on market factors. For both linkages, future studies should consider additional attributes beyond transparency and institutional support. Institutional stability, institutional void and industry competition - established constructs in $\mathrm{IB}$ - could be informative antecedents. That there are few studies probing the link between market factors and dynamic capabilities (1c-2e) is startling given the linkage proffers the "forged in fire" mantra - change or turbulence sets the stage for dynamic capabilities. Are threats superior to opportunities in fostering dynamic capabilities? Are there diminishing returns to the development of dynamic capabilities vis-à-vis duration and magnitude of change? These questions should motivate subsequent studies to delve deeper into the relationship between market factors and dynamic capabilities.

We encourage future research to examine another three under-researched linkages (i.e. $2 d-3 g, 2 e-3 f$ and $2 e-3 g$ ). Concerning operational capabilities and survival (2d-3g), the handful studies indicate a link between marketing and management capabilities, and survival or 
business longevity. Yet, from a conceptual basis, the impact of operational capabilities on survival should be rather limited given operational capabilities allow born globals and international new ventures to be "in the game" as opposed to winning it over the long haul. Additional research on this linkage will provide clarity.

Two of the three linkages (i.e. $2 e-3 f$ and $2 e-3 g$ ) involving dynamic capabilities and their outcomes demand further scrutiny. The paucity of studies exploring the link between dynamic capabilities and precocity (2e-3f) probably arises from the challenge of determining which capabilities are salient when internationalization commences. The reverse causal relationship - precocity triggers the development of dynamic capabilities - is worth exploring in subsequent research. That the investigation of the linkage between dynamic capabilities and survival $(2 e-3 g)$ is confined to two studies was completely unanticipated. In principle, survival represents the very outcome where the efficacy of dynamic capabilities (i.e. the effect of constant adaptation on business longevity) should be evident. We encourage researchers to expand this linkage beyond the two studies we identified.

\section{Conclusions and implications}

Arguing that the growth of knowledge products in IE now exceeds our ability to remember, organize, or use extant literature, we conducted a systematic literature review on the capabilities underpinning the early internationalization of born globals and international new ventures. Several recent studies (Al-Aali and Teece, 2014; Coviello, 2015; İpek, 2018; Jie et al., 2021; Øyna and Alon, 2018; Nguyen and Mort, 2020; Pinho and Prange, 2016), which advocate the advancement of knowledge on capabilities, provided additional motivation for this review. We identified 13 capabilities which we bifurcated into eight operational (i.e. networking, entrepreneurial, marketing, knowledge and learning, innovation, financing, technology, management) and 5 higher-level (i.e. absorptive capacity, ambidexterity, dynamic managerial, dynamic learning and dynamic social) capabilities. Content analysis and constant comparison method enabled us to draw three antecedents (i.e. firm specific factors, managerial socio cognitive attributes and market factors) and three outcomes (i.e. precocity, survival and performance), before linking these to operational and dynamic capabilities. A narrative synthesis of the 12 linkages and the summary in Figure 5 mark the pinnacle of our contribution.

\subsection{Implications for theory}

Our synthesis has shown that just 7 of the 12 linkages are well-established. Regarding antecedents, we know more about the effects of firm specific factors and managerial socio cognitive attributes on operational and dynamic capabilities than we do the influence of market factors on either group of capabilities. Correspondingly, we know more about the influence of operationaland dynamic capabilities on performance than we do their impact on precocity or survival. As a general observation, linkages involving market factors (i.e. as an antecedent), survival (i.e. as an outcome) and dynamic capabilities (i.e. both antecedent-capability and capability-outcome) are scantily researched. We have directed future studies to investigate the specific under-researched links comprising market factors and operational capabilities; market factors and dynamic capabilities; operational capabilities and survival; dynamic capabilities and precocity; and dynamic capabilities and survival. There is an opportunity for subsequent studies to make greater use of the institutional perspective to enrich the theoretical robustness of relationships involving market factors. Likewise, scholarship on dynamic capabilities (as an antecedent or outcome) will benefit from the nuanced view on the social aggregation of individuals, processes and structures, the microfoundations perspective affords.

The gaps in knowledge we have underlined not only indicate that our understanding of the origin of capabilities is incomplete but also they signal we have a partial grasp of the 
influence of capabilities on precocity, survival and performance. On the one hand, we add to niche strands of research such as strategic orientations and born globals (Jantunen et al., 2008; Evers et al., 2019), on the other, our review speaks to a wider community beyond early internationalization. For instance, our portrayal of the link between operational and dynamic capabilities adds to a sub-stream of management/strategy research (Cepeda and Vera, 2007; Newey and Zahra, 2009) studying this conundrum.

\subsection{Implications for policymaking}

McNaughton and colleagues (Bell and McNaughton, 2000; McNaughton and Pellegrino, 2014) argue early internationalization presents a unique challenge to policymaking in that it does not lend itself to traditional need-based firm segmentation typologies. Yet, within this discourse, the role of policymaker-driven export promotion programmes in fostering capabilities is incontrovertible. What is the most effective way of tailoring such support for born globals and international new ventures?

Our review documented the criticality of managerial profiles to capability building. Attitudinal and behavioural states largely explain the divergent capacities to foster operational and dynamic capabilities. We argue that unlike traditional export research which segments exporters using firm demographics, managerial profiles provide an alternative criterion for targeted policymaker support. While the notion of targeting by managerial profiles is not entirely a novel concept (Gray, 1997), it has remained peripheral to the early internationalization discourse. We submit that targeting gaps in skills, knowledge and international exposure and providing other immersive experiences stimulates the attitudinal and behavioural states critical for enhancing capability development.

\subsection{Implications for practice}

The task of developing, upgrading and renewing capabilities falls squarely on the focal organization. Our review amplifies, for practitioners, the significance of choosing and embracing appropriate forms of strategic orientations. In this regard the question Jantunen et al. (2008) adopt as the title of their manuscript: "Strategic orientations of born globals - Do they really matter?" can be answered in the affirmative. To varying degrees, competitor-, customer-, entrepreneurial-, global-, learning- and market orientation influence both operational and dynamic capabilities. Thus, our review suggests it is not so much the resources at the venture's disposal as it is the decision maker's ability to pivot the organization, which engenders capability development.

The COVID-19 pandemic underscores the practical utility of capabilities. For instance, the link between market factors (e.g. uncertainty and dynamism) and capability development means that this once-in-a-century exogenous shock provides an ideal setting (i.e. the impetus) to upgrade, renew and reconfigure capabilities. Firms with the right strategic orientations and appropriate managerial socio cognitive attributes are well-placed to adjust and seize opportunities. As the pandemic has shown, businesses with adaptable capabilities (e.g. shifting from a brick and mortar to an online/omnichannel approach or micro-breweries competent to switch from manufacturing beer to hand sanitizer) have increased their chance of survival while helping society cope.

Our study comes with limitations. Although we used a systematic approach to search, qualify and organize the literature, other studies fitting the objective of this research may have been missed. We adopted synthesis by integration which is inferior to vote-counting or statistical meta-analysis. While the hazy nature of both early internationalization and capabilities justified our approach, we caution readers against making wholesale causal inferences from the synthesis. Our review has tackled the daunting amorphous concept of capabilities and provided guidance for future studies. 
1. They combine Jones et al.'s (2011) list with ongoing updates to the International Entrepreneurship Scholar's website See http://ie-scholars.net/

2. Chetty and Campbell-Hunt won the American Marketing Association's - 2009, Hans B. Thorelli Award.

3. Note, many factors influence this metric. We use this only as a rudimentary indicator.

4. See Autio et al. (2011) for a description of "repeated exposure to situation uncertainty."

5. See, in exact order, Ayadi-Frikha (2014), Filatotchev and Piesse (2009) and Odlin and Benson-Rea (2017).

\section{References}

Abrahamsson, J., Boter, H. and Vanyushyn, V. (2019), "Business model innovation of international new ventures: an empirical study in a Swedish context”, Journal of International Entrepreneurship, Vol. 17 No. 1, pp. 75-102.

Adner, R. and Helfat, C.E. (2003), "Corporate effects and dynamic managerial capabilities", Strategic Management Journal, Vol. 24 No. 10, pp. 1011-1025.

Al-Aali, A. and Teece, D.J. (2014), "International entrepreneurship and the theory of the (long-lived) international firm: a capabilities perspective", Entrepreneurship Theory and Practice, Vol. 38 No. 1, pp. 95-116.

Alam, M.N., Masroor, I. and Nabi, M.N.U. (2020), “Does entrepreneurs' risk perception influence firm's rapidity in foreign market entry through moderation of entrepreneurial decision-making approach?", Review of International Business and Strategy, Vol. 30 No. 2, pp. 225-243.

Altshuler, L. and Tarnovskaya, V.V. (2010), "Branding capability of technology born globals", Journal of Brand Management, Vol. 18 No. 3, pp. 212-227.

Alvesson, M. and Sandberg, J. (2011), "Generating research questions through problematization", Academy of Management Review, Vol. 36 No. 2, pp. 247-271.

Amorós, J.E., Basco, R. and Romaní, G. (2016), "Determinants of early internationalization of new SMEs: the case of Chile", International Entrepreneurship and Management Journal, Vol. 12 No. 1, pp. 283-307.

Andersson, S. and Evers, N. (2015), "International opportunity recognition in international new ventures a dynamic managerial capabilities perspective", Journal of International Entrepreneurship, Vol. 13 No. 3, pp. 260-276.

Andersson, S. and Wictor, I. (2003), "Innovative internationalization in new SMEs: born globals - the nterna case", Journal of International Entrepreneurship, Vol. 1 No. 3, pp. 249-275.

Andersson, S., Evers, N. and Gliga, G. (2018), "Entrepreneurial marketing and born global internationalisation in China", Qualitative Market Research, Vol. 21 No. 2, pp. 202-231.

Armstrong, R., Hall, B.J., Doyle, J. and Waters, E. (2011), “Scoping the scope' of a nternat review”, Journal of Public Health, Vol. 33 No. 1, pp. 147-150.

Arte, P. (2017), "Role of experience and knowledge in early nternationalisation of Indian new ventures: a comparative case study", International Journal of Entrepreneurial Behavior and Research, Vol. 23 No. 6, pp. 850-865.

Aspelund, A., Azari, M.J., Aglen, A.F. and Graff, S.G. (2018), "The birth and development of a born global industry: the case of microelectronics in Norway", Journal of International Entrepreneurship, Vol. 16 No. 1, pp. 82-108.

Aspelund, A., Koed Madsen, T. and Moen, Ø. (2007), "A review of the foundation, international marketing strategies, and performance of international new ventures", European Journal of Marketing, Vol. 41 Nos 11/12, pp. 1423-1448. 
Autio, E., George, G. and Alexy, O. (2011), "International entrepreneurship and capability development - qualitative evidence and future research directions", Entrepreneurship Theory and Practice, Vol. 35 No. 1, pp. 11-37.

Ayadi-Frikha, M. (2014), "Cognitive map for identifying the determinants of the early and rapidly internationalizing SMEs", Journal of the Knowledge Economy, Vol. 5 No. 3, pp. 633-645.

Baier-Fuentes, H., Merigó, J.M., Amorós, J.E. and Gaviria-Marin, M. (2018), "International entrepreneurship: a bibliometric overview", International Entrepreneurship and Management Journal, Vol. 15 No. 2, pp. 385-429.

Barney, J.B. (2001), "Resource-based theories of competitive advantage: a ten-year retrospective on the resource-based view", Journal of Management, Vol. 27 No. 6, pp. 643-650.

Barney, J.A.Y. and Felin, T. (2013), "What are microfoundations?", Academy of Management Perspectives, Vol. 27 No. 2, pp. 138-155.

Baronchelli, G. and Cassia, F. (2014), "Exploring the antecedents of born-global companies' international development”, International Entrepreneurship and Management Journal, Vol. 10 No. 1, pp. 67-79.

Baum, M., Schwens, C. and Kabst, R. (2011), "A typology of international new ventures: empirical evidence from high-technology industries", Journal of Small Business Management, Vol. 49 No. 3, pp. 305-330.

Baum, M., Schwens, C. and Kabst, R. (2015), “A latent class analysis of small SMEs' internationalization patterns", Journal of World Business, Vol. 50 No. 4, pp. 754-768.

Bell, J. and McNaughton, R. (2000), "Born global SMEs: a challenge to public policy in support of internationalization", Marketing in a Global Economy, Vol. 1, pp. 176-185.

Bembom, M. and Schwens, C. (2018), "The role of networks in early internationalizing SMEs: a systematic review and future research agenda", European Management Journal, Vol. 36 No. 6, pp. 679-694.

Blesa, A., Monferrer, D., Nauwelaerts, Y. and Ripollés, M. (2008), "The effect of early international commitment on international positional advantages in Spanish and Belgian international new ventures", Journal of International Entrepreneurship, Vol. 6 No. 4, pp. 168-187.

Boehe, D.M. (2009), "Brazilian software SME's export propensity: bridging 'born global' and stage approaches", Latin American Business Review, Vol. 1 Nos 2/3, pp. 187-216.

Boermans, M.A. and Roelfsema, H. (2013), "The effects of managerial capabilities on export, FDI and innovation: evidence from Indian SMEs”, Asian Business and Management, Vol. 12 No. 4, pp. 387-408.

Bourdieu, P. and Wacquant, L.J.D. (1992), An Invitation to Reflexive Sociology, Chicago, University of Chicago Press.

Briner, R.B., Denyer, D. and Rousseau, D.M. (2009), "Evidence-based management: concept clean-up time?", Academy of Management Perspectives, Vol. 23 No. 4, pp. 19-32.

Bruneel, J., Yli-Renko, H. and Clarysse, B. (2010), "Learning from experience and learning from others: how congenital and interorganizational learning substitute for experiential learning in young firm internationalization", Strategic Entrepreneurship Journal, Vol. 4 No. 2, pp. 64-182.

Bunz, T., Casulli, L., Jones, M.V. and Bausch, A. (2017), "The dynamics of experiential learning: Microprocesses and adaptation in a professional service INV", International Business Review, Vol. 26 No. 2, pp. 225-238.

Cannone, G. and Ughetto, E. (2014), "Born globals: a cross-country survey on high-tech start-ups", International Business Review, Vol. 23 No. 1, pp. 272-283.

Cabrol, M., Favre-Bonte, V. and Fayolle, A. (2009), "The influence of the entrepreneur's network on the internationalization of young French firms", The International Journal of Entrepreneurship and Innovation, Vol. 10 No. 3, pp. 213-221.

Cavusgil, S.T. and Knight, G. (2015), "The born global firm: an entrepreneurial and capabilities perspective on early and rapid internationalization”, Journal of International Business Studies, Vol. 46 No. 1, pp. 3-16. 
Cepeda, G. and Vera, D. (2007), "Dynamic capabilities and operational capabilities: a knowledge management perspective", Journal of Business Research, Vol. 60 No. 5, pp. 426-437.

Cesinger, B., Fink, M., Koed Madsen, T. and Kraus, S. (2012), "Rapidly internationalizing ventures: how definitions can bridge the gap across contexts", Management Decision, Vol. 50 No. 10, pp. 1816-1842.

Chen, J.S. and Lovvorn, A.S. (2011), "The speed of knowledge transfer within multinational enterprises: the role of social capital", International Journal of Commerce and Management, Vol. 21 No. 1, pp. 46-62.

Chetty, S. and Agndal, H. (2007), "Social capital and its influence on changes in internationalization mode among small and medium-sized enterprises", Journal of International Marketing, Vol. 15 No. 1, pp. 1-29.

Chetty, S. and Campbell-Hunt, C. (2004), "A strategic approach to internationalization: a traditional versus a 'born-global' approach”, Journal of International Marketing, Vol. 12 No. 1, pp. 57-81.

Chin, T., Liu, R.H. and Yang, X. (2016), "Reverse internationalization' in Chinese SMEs: a study of how global start-up OEMs seek to compete domestically”, Asia Pacific Business Review, Vol. 22 No. 2, pp. 201-219.

Collins, R. (1981), "On the microfoundations of macrosociology", American Journal of Sociology, Vol. 86 No. 5, pp. 984-1014.

Collis, D.J. (1994), "Research note: how valuable are organizational capabilities?", Strategic Management Journal, Vol. 15 No. S1, pp. 143-152.

Coudounaris, D.N. (2018), “Typologies of internationalization pathways of SMEs: what is new?”, Review of International Business and Strategy, Vol. 28 Nos 3/4, pp. 286-316.

Coudounaris, D.N. and Arvidsson, H.G.S. (2021), "How effectuation, causation and bricolage influence the international performance of firms via internationalization strategy: a literature review", Review of International Business and Strategy, doi: 10.1108/RIBS-08-2020-0092.

Coviello, N. (2015), "Re-thinking research on born globals", Journal of International Business Studies, Vol. 46 No. 1, pp. 17-26.

Coviello, N.E. and Jones, M.V. (2004), "Methodological issues in international entrepreneurship research", Journal of Business Venturing, Vol. 19 No. 4, pp. 485-508.

Covin, J.G. and Miller, D. (2014), "International entrepreneurial orientation: conceptual considerations, research themes, measurement issues, and future research directions", Entrepreneurship Theory and Practice, Vol. 38 No. 1, pp. 11-44.

Day, G.S. (1994), "The capabilities of market-driven organizations”, Journal of Marketing, Vol. 58 No. 4, pp. 37-52.

De Clercq, D., Sapienza, H.J., Yavuz, R.I. and Zhou, L. (2012), "Learning and knowledge in early internationalization research: past accomplishments and future directions", Journal of Business Venturing, Vol. 27 No. 1, pp. 143-165.

De Clercq, D. and Zhou, L. (2014), "Entrepreneurial strategic posture and performance in foreign markets: the critical role of international learning effort", Journal of International Marketing, Vol. 22 No. 2, pp. 47-67.

Debrulle, J. and Maes, J. (2015), "Start-ups' internationalization: the impact of business owners' management experience, start-up experience and professional network on export intensity", European Management Review, Vol. 12 No. 3, pp. 171-187.

Dib, L.A., Da Rocha, A. and Da Silva, J.F. (2010), "The internationalization process of Brazilian software firms and the born global phenomenon: examining firm, network, and entrepreneur variables", Journal of International Entrepreneurship, Vol. 8 No. 3, pp. 233-253.

Dike, M.C. and Rose, E.L. (2017), "Internationalization of mobile telecommunications: a systematic literature review", Review of International Business and Strategy, Vol. 27 No. 3, pp. 308-321.

Domurath, A. and Patzelt, H. (2016), "Entrepreneurs' assessments of early international entry: the role of foreign social ties, venture absorptive capacity, and generalized trust in others", Entrepreneurship Theory and Practice, Vol. 40 No. 5, pp. 1149-1177. 
Dow, D. (2017), "Born global firms and accidental internationalists: has Hennart (2014) opened a can of worms?", Review of International Business and Strategy, Vol. 27 No. 3, pp. 286-307.

Dzikowski, P. (2018), "A bibliometric analysis of born global SMEs", Journal of Business Research, Vol. 85, pp. 281-294.

Edmondson, A.C. and McManus, S.E. (2007), "Methodological fit in management field research", Academy of Management Review, Vol. 32 No. 4, pp. 1246-1264.

Efrat, K., Gilboa, S. and Yonatany, M. (2017), "When marketing and innovation interact: the case of born-global SMEs", International Business Review, Vol. 26 No. 2, pp. 380-390.

Efrat, K. and Shoham, A. (2012), "Born global SMEs: the differences between their short-and long-term performance drivers", Journal of World Business, Vol. 47 No. 4, pp. 675-685.

Evangelista, F. (2005), "Qualitative insights into the international new venture creation process", Journal of International Entrepreneurship, Vol. 3 No. 3, pp. 179-198.

Evers, N. (2011), "International new ventures in 'low tech' sectors: a dynamic capabilities perspective", Journal of Small Business and Enterprise Development, Vol. 18 No. 3, pp. 502-528.

Evers, N., Andersson, S. and Hannibal, M. (2012), "Stakeholders and marketing capabilities in international new ventures: evidence from Ireland, Sweden and Denmark", Journal of International Marketing, Vol. 20 No. 4, pp. 46-71.

Evers, N., Gliga, G. and Rialp-Criado, A. (2019), "Strategic orientation pathways in international new ventures and born global SMEs-towards a research agenda", Journal of International Entrepreneurship, Vol. 17 No. 3, pp. 287-304.

Fainshmidt, S., Smith, A.W. and Aguilera, R.V. (2021), "Where do born globals come from? A neoconfigurational institutional theory”, Organization Science, pp. 1-22, doi: 10.1287/orsc.2021.1497

Falahat, M., Knight, G. and Alon, I. (2018), "Orientations and capabilities of born global SMEs from emerging markets”, International Marketing Review, Vol. 35 No. 6, pp. 936-957.

Falahat, M., Migin, M.W., Chuan, C.S. and Kong, P.F. (2015), "Conceptualizing the early and rapid internationalizing SMEs", Procedia - Social and Behavioral Sciences, Vol. 211, pp. 612-618.

Falay, Z., Salimäki, M., Ainamo, A. and Gabrielsson, M. (2007), "Design-intensive born globals: a multiple case study of marketing management", Journal of Marketing Management, Vol. 23 Nos 9/10, pp. 877-899.

Felin, T. and Hesterly, W.S. (2007), “The knowledge-based view, nested heterogeneity, and new value creation: philosophical considerations on the locus of knowledge", Academy of Management Review, Vol. 32 No. 1, pp. 195-218.

Felin, T., Foss, N.J., Heimeriks, K.H. and Madsen, T.L. (2012), "Microfoundations of routines and capabilities: individuals, processes, and structure", Journal of Management Studies, Vol. 49 No. 8, pp. 1351-1374.

Filatotchev, I. and Piesse, J. (2009), "R\&D, internationalization, and growth of newly listed SMEs: European evidence", Journal of International Business Studies, Vol. 40 No. 8, pp. 1260-1276.

Fletcher, M. and Prashantham, S. (2011), "Knowledge assimilation processes of rapidly internationalizing SMEs", Journal of Small Business and Enterprise Development, Vol. 18 No. 3, pp. 475-501.

Freeman, S. and Cavusgil, S.T. (2007), "Toward a typology of commitment states among managers of born-global SMEs: a study of accelerated internationalization”, Journal of International Marketing, Vol. 15 No. 4, pp. 1-40.

Freeman, S., Hutchings, K. and Chetty, S. (2012), "Born-globals and culturally proximate markets", Management International Review, Vol. 52 No. 3, pp. 425-460.

Freeman, S., Hutchings, K., Lazaris, M. and Zyngier, S. (2010), “A model of rapid knowledge development: the smaller born-global firm”, International Business Review, Vol. 19 No. 1, pp. 70-84.

Fuerst, S. and Zettinig, P. (2015), "Knowledge creation dynamics within the international new venture", European Business Review, Vol. 27 No. 2, pp. 182-213. 
Gabrielsson, P. and Gabrielsson, M. (2013), “A dynamic model of growth phases and survival in international business-to-business new ventures: the moderating effect of decision-making logic", Industrial Marketing Management, Vol. 42 No. 8, pp. 1357-1373.

Gabrielsson, M., Gabrielsson, P. and Dimitratos, P. (2014), "International entrepreneurial culture and growth of international new ventures", Management International Review, Vol. 54 No. 4, pp. 445-471.

Gabrielsson, M., Kirpalani, V.M., Dimitratos, P., Solberg, C.A. and Zucchella, A. (2008), "Conceptualizations to advance born global definition: a research note", Global Business Review, Vol. 9 No. 1, pp. 45-50.

Gabrielsson, M., Sasi, V. and Darling, J. (2004), "Finance strategies of rapidly-growing finnish SMEs: born internationals and born globals", European Business Review, Vol. 16 No. 6, pp. 590-604.

García-Cabrera, A.M., García-Soto, M.G. and Suárez-Ortega, S.M. (2017), "Macro-level spillovers and microlevel capabilities as antecedents of young SMEs' propensity to export and to become a born global", International Entrepreneurship and Management Journal, Vol. 13 No. 4, pp. 1199-1220.

García-Lillo, F., Claver-Cortés, E., Marco-Lajara, B. and Úbeda-García, M. (2017), "Mapping the intellectual structure of research on 'born global' SMEs and INVs: a citation/co-citation analysis", Management International Review, Vol. 57 No. 4, pp. 631-652.

Gaur, A.S., Kumar, V. and Singh, D. (2014), "Institutions, resources, and internationalization of emerging economy firms”, Journal of World Business, Vol. 49 No. 1, pp. 12-20.

Gerschewski, S., Lew, Y.K., Khan, Z. and Park, B.I. (2018), "Post-entry performance of international new ventures: the mediating role of learning orientation", International Small Business Journal, Vol. 36 No. 7, pp. 807-828.

Gerschewski, S., Lindsay, V.J. and Rose, E. (2016), "Advancing the entrepreneurial orientation construct: the role of passion and perseverance", Review of International Business and Strategy, Vol. 26 No. 4, pp. 446-471.

Gerschewski, S., Rose, E.L. and Lindsay, V.J. (2015), "Understanding the drivers of international performance for born global SMEs: an integrated perspective", Journal of World Business, Vol. 50 No. 3, pp. 558-575.

Grant, R.M. (1996), "Toward a knowledge-based theory of the firm”, Strategic Management Journal, Vol. 17 NO. S2, pp. 109-122.

Graves, C. and Thomas, J. (2006), "Internationalization of Australian family businesses: a managerial capabilities perspective”, Family Business Review, Vol. 19 No. 3, pp. 207-224.

Gray, B.J. (1997), "Profiling managers to improve export promotion targeting", Journal of International Business Studies, Vol. 28 No. 2, pp. 387-420.

Gulanowski, D., Papadopoulos, N. and Plante, L. (2018), "The role of knowledge in international expansion: toward an integration of competing models of internationalization", Review of International Business and Strategy, Vol. 28 No. 1, pp. 35-60.

Hagen, B. and Zucchella, A. (2014), "Born global or born to run? The long-term growth of born global firms", Management International Review, Vol. 54, pp. 497-525.

Hallbäck, J. and Gabrielsson, P. (2013), "Entrepreneurial marketing strategies during the growth of international new ventures originating in small and open economies", International Business Review, Vol. 22 No. 6, pp. 1008-1020.

Han, M. and Celly, N. (2008), "Strategic ambidexterity and performance in international new ventures", Canadian Journal of Administrative Sciences/Revue Canadienne Des Sciences de L'administration, Vol. 25 No. 4, pp. 335-349.

Hashai, N. (2011), "Sequencing the expansion of geographic scope and foreign operations by "born global' firms", Journal of International Business Studies, Vol. 42 No. 8, pp. 995-1015.

Haskell, N., Veilleux, S. and Béliveau, D. (2016), "Operational and contextual dimensions of INVs' alliance partner selection”, Journal of International Entrepreneurship, Vol. 14 No. 4, pp. 483-512. 
Hennart, J.F. (2014), "The accidental internationalists: a theory of born globals", Entrepreneurship Theory and Practice, Vol. 38 No. 1, pp. 117-135.

Huang, Y.H. and Hsieh, H.M. (2013), "The accelerated internationalization of born global firms: a knowledge transformation process view”, Journal of Asia Business Studies, Vol. 7 No. 3, pp. 244-261.

Huber, G.P. (1991), "Organizational learning: the contributing processes and the literatures", Organization Science, Vol. 2 No. 1, pp. 88-115.

Hughes, M., Cesinger, B., Cheng, C.F., Schuessler, F. and Kraus, S. (2019), "A configurational analysis of network and knowledge variables explaining born globals' and late internationalizing SMEs' international performance", Industrial Marketing Management, Vol. 80, pp. 172-187.

Hughes, M., Martin, S.L., Morgan, R.E. and Robson, M.J. (2010), "Realizing product-market advantage in high-technology international new ventures: the mediating role of ambidextrous innovation", Journal of International Marketing, Vol. 18 No. 4, pp. 1-21.

İpek, İ. (2018), "The resource-based view within the export context: an integrative review of empirical studies", Journal of Global Marketing, Vol. 31 No. 3, pp. 157-179.

İpek, İ. (2019), "Organizational learning in exporting: a bibliometric analysis and critical review of the empirical research", International Business Review, Vol. 23 No. 3, pp. 544-559.

Jantunen, A., Nummela, N., Puumalainen, K. and Saarenketo, S. (2008), "Strategic orientations of born globals - do they really matter?”, Journal of World Business, Vol. 43 No. 2, pp. 158-170.

Jantunen, A., Puumalainen, K., Saarenketo, S. and Kyläheiko, K. (2005), "Entrepreneurial orientation, dynamic capabilities and international performance", Journal of International Entrepreneurship, Vol. 3 No. 3, pp. 223-243.

Ji, F.X., Axinn, C.N. and Antunes Garcia de Campos, L. (2018), "Exploring high-commitment international growth of high-technology new ventures: the contingent model of formal alliances", International Studies of Management \& Organization, Vol. 48 No. 2, pp. 204-220.

Ji, J., Plakoyiannaki, E., Dimitratos, P. and Chen, S. (2019), "The qualitative case research in international entrepreneurship: a state of the art and analysis", International Marketing Review, Vol. 36 No. 1, pp. 164-187.

Jie, S., Harms, R., Groen, A.J. and Jones, P. (2021), "Capabilities and performance of early internationalizing firms: a systematic literature review”, Journal of Small Business Management, pp. 1-31, doi: 10.1080/00472778.2021.1955124.

Johanson, J. and Vahlne, J.E. (2003), "Business relationship learning and commitment in the internationalization process", Journal of International Entrepreneurship, Vol. 1 No. 1, pp. 83-101.

Jones, M.V., Coviello, N. and Tang, Y.K. (2011), "International entrepreneurship research (1989-2009): a domain ontology and thematic analysis", Journal of Business Venturing, Vol. 26 No. 6, pp. 632-659.

Kahiya, E.T. (2018), "Five decades of research on export barriers: review and future directions", International Business Review, Vol. 27 No. 6, pp. 1172-1188.

Kahiya, E.T. (2020), "Context in international business: entrepreneurial internationalization from a distant small open economy", International Business Review, Vol. 29 No. 1, p. 101621.

Kang, J.H. and Jin, B. (2007), "Determinants of born global firm growth in the apparel industry: a Korean case", Journal of the Textile Institute, Vol. 98 No. 2, pp. 137-146.

Karatepe, O.M., Uner, M.M. and Kocak, A. (2016), "Investigating the impact of customer orientation on innovativeness: evidence from born-global SMEs in Turkey", Economic Research-Ekonomska Istraživanja, Vol. 29 No. 1, pp. 721-757.

Karra, N., Phillips, N. and Tracey, P. (2008), "Building the born global firm: developing entrepreneurial capabilities for international new venture success", Long Range Planning, Vol. 41 No. 4, pp. 440-458.

Kaur, S. and Sandhu, M.S. (2014), "Internationalisation of born global firms: evidence from Malaysia", Journal of the Asia Pacific Economy, Vol. 19 No. 1, pp. 101-136.
Review and synthesis 
Keupp, M.M. and Gassmann, O. (2009), "The past and the future of international entrepreneurship: a review and suggestions for developing the field", Journal of Management, Vol. 35 No. 3, pp. 600-633.

Khalid, S. and Larimo, J. (2012), "Affects of alliance entrepreneurship on common vision, alliance capability and alliance performance", International Business Review, Vol. 21 No. 5, pp. 891-905.

Khan, Z. and Lew, Y.K. (2018), "Post-entry survival of developing economy international new ventures: a dynamic capability perspective", International Business Review, Vol. 27 No. 1, pp. 149-160.

Khanna, T. (2014), “Contextual intelligence”, Harvard Business Review, Vol. 92 No. 9, pp. 58-68.

Khavul, S., Pérez-Nordtvedt, L. and Wood, E. (2010), "Organizational entrainment and international new ventures from emerging markets", Journal of Business Venturing, Vol. 25 No. 1, pp. 104-119.

Khavul, S., Peterson, M., Mullens, D. and Rasheed, A.A. (2010), "Going global with innovations from emerging economies: investment in customer support capabilities pays off", Journal of International Marketing, Vol. 18 No. 4, pp. $22-42$.

Kim, D., Basu, C., Naidu, G.M. and Cavusgil, E. (2011), "The innovativeness of born-globals and customer orientation: learning from Indian born-globals", Journal of Business Research, Vol. 64 No. 8, pp. 879-886.

Kiss, A.N. and Danis, W.M. (2008), "Country institutional context, social networks, and new venture internationalization speed", European Management Journal, Vol. 26 No. 6, pp. 388-399.

Knight, G.A. and Cavusgil, S.T. (2004), "Innovation, organizational capabilities, and the born-global firm”, Journal of International Business Studies, Vol. 35 No. 2, pp. 124-141.

Knight, G.A. and Cavusgil, S.T. (2005), "A taxonomy of born-global SMEs”, Management International Review, Vol. 45 No. 3, pp. 15-35.

Knight, G.A. and Kim, D. (2009), "International business competence and the contemporary firm", Journal of International Business Studies, Vol. 40 No. 2, pp. 255-273.

Knight, G.A. and Liesch, P.W. (2016), “Internationalization: from incremental to born global”, Journal of World Business, Vol. 51 No. 1, pp. 93-102.

Knight, G., Madsen, T.K. and Servais, P. (2004), "An inquiry into born-global SMEs in Europe and the USA”, International Marketing Review, Vol. 21 No. 6, pp. 645-665.

Kocak, A. and Abimbola, T. (2009), "The effects of entrepreneurial marketing on born global performance", International Marketing Review, Vol. 26 Nos 4/5, pp. 439-452.

Kollmann, T. and Christofor, J. (2014), "International entrepreneurship in the network economy: internationalization propensity and the role of entrepreneurial orientation", Journal of International Entrepreneurship, Vol. 12 No. 1, pp. 43-66.

Kostova, T., Roth, K. and Dacin, M.T. (2008), "Institutional theory in the study of multinational corporations: a critique and new directions", Academy of Management Review, Vol. 33 No. 4, pp. 994-1006.

Kowalik, I., Danik, L. and Sikora, T. (2017), "Entrepreneurial orientation elements in the Polish international new ventures", Baltic Journal of Management, Vol. 12 No. 2, pp. 194-213.

Kraus, S., Niemand, T., Angelsberger, M., Mas-Tur, A. and Roig-Tierno, N. (2017), "Antecedents of international opportunity recognition in born global SMEs", Journal of Promotion Management, Vol. 23 No. 3, pp. 386-406.

Kuivalainen, O., Puumalainen, K., Sintonen, S. and Kyläheiko, K. (2010), "Organizational capabilities and internationalization of the small and medium-sized information and communications technology SMEs", Journal of International Entrepreneurship, Vol. 8 No. 2, pp. 135-155.

Kuivalainen, O., Sundqvist, S. and Servais, P. (2007), "SMEs' degree of born-globalness, international entrepreneurial orientation and export performance", Journal of World Business, Vol. 42 No. 3, pp. 253-267. 
Kumar, N. (2012a), "International entrepreneurship: case of happiest minds", South Asian Journal of Business and Management Cases, Vol. 1 No. 1, pp. 17-30.

Kumar, N. (2012b), "The resource dynamics of early internationalizing Indian IT firms", Journal of

Review and synthesis International Entrepreneurship, Vol. 10, pp. 255-278.

Kumar, N. (2013), "Internationalization of Indian knowledge-intensive service SMEs: learning as an antecedent to entrepreneurial orientation", Asian Business and Management, Vol. 12 No. 5, pp. 503-523.

Kumar, N. and Yakhlef, A. (2014), "How capabilities evolve in a born global firm? A case study of an Indian knowledge-intensive service born global firm”, Journal of Entrepreneurship in Emerging Economies, Vol. 6 No. 3, pp. 223-242.

Kungwansupaphan, C. and Siengthai, S. (2014), "Exploring entrepreneurs' human capital components and effects on learning orientation in early internationalizing SMEs", International Entrepreneurship and Management Journal, Vol. 10 No. 3, pp. 561-587.

Kyläheiko, K., Jantunen, A., Puumalainen, K., Saarenketo, S. and Tuppura, A. (2011), "Innovation and internationalization as growth strategies: the role of technological capabilities and appropriability", International Business Review, Vol. 20 No. 5, pp. 508-520.

Kyvik, O., Saris, W., Bonet, E. and Felício, J.A. (2013), "The internationalization of small firms: the relationship between the global mindset and firms' internationalization behavior", Journal of International Entrepreneurship, Vol. 11 No. 2, pp. 172-195.

Laanti, R., Gabrielsson, M. and Gabrielsson, P. (2007), "The globalization strategies of business-tobusiness born global SMEs in the wireless technology industry", Industrial Marketing Management, Vol. 36 No. 8, pp. 1104-1117.

Laudien, S.M. and Daxböck, B. (2017), "Enhancing the understanding of international new ventures: a service-oriented perspective", Management Research Review, Vol. 40 No. 5, pp. 494-516.

Laurell, H., Achtenhagen, L. and Andersson, S. (2017), "The changing role of network ties and critical capabilities in an international new venture's early development", International Entrepreneurship and Management Journal, Vol. 13 No. 1, pp. 113-140.

Leonard-Barton, D. (1992), "Core capabilities and core rigidities: a paradox in managing new product development”, Strategic Management Journal, Vol. 13 No. S1, pp. 111-125.

Levitt, B. and March, J.G. (1988), “Organizational learning”, Annual Review of Sociology, Vol. 14 No. 1, pp. 319-338.

Li, M., He, X. and Sousa, C.M. (2017), "A review of the empirical research on export channel selection between 1979 and 2015”, International Business Review, Vol. 26 No. 2, pp. 303-323.

Li, L., Qian, G. and Qian, Z. (2012), "Early internationalization and performance of small high-tech "born-globals", International Marketing Review, Vol. 29 No. 5, pp. 536-561.

Lin, S., Mercier-Suissa, C. and Salloum, C. (2016), "The Chinese born globals of the Zhejiang province: a study on the key factors for their rapid internationalization”, Journal of International Entrepreneurship, Vol. 14 No. 1, pp. 75-95.

Lin, S. and Si, S. (2019), "The influence of exploration and exploitation on born globals' speed of internationalization", Management Decision, Vol. 57 No. 1, pp. 193-210.

Lopez-Morales, J.S. (2018), "Multilatinas: a systematic literature review", Review of International Business and Strategy, Vol. 28 Nos 3/4, pp. 331-357.

Loufrani-Fedida, S., Hauch, V. and Elidrissi, D. (2019), "The dynamics of relational competencies in the development of born global SMEs: a multilevel approach", International Business Review, Vol. 28 No. 2, pp. 222-237.

McNaughton, R.B. and Pellegrino, J. (2014), "Policy implications of international entrepreneurship", The Routledge Companion to International Entrepreneurship, pp. 233-244. 
MacLure, M. (2005), “Clarity bordering on stupidity': where's the quality in systematic review?”, Journal of Education Policy, Vol. 20 No. 4, pp. 393-416.

Madsen, T.K. (2013), "Early and rapidly internationalizing ventures: similarities and differences between classifications based on the original international new venture and born global literatures", Journal of International Entrepreneurship, Vol. 11 No. 1, pp. 65-79.

Madsen, T.K. and Servais, P. (1997), "The internationalization of born globals: an evolutionary process", International Business Review, Vol. 6 No. 6, pp. 561-583.

Mainela, T., Puhakka, V. and Servais, P. (2014), "The concept of international opportunity in international entrepreneurship: a review and a research agenda", International Journal of Management Reviews, Vol. 16 No. 1, pp. 105-129.

Manolova, T.S., Manev, I.M. and Gyoshev, B.S. (2010), "In good company: the role of personal and interfirm networks for new-venture internationalization in a transition economy", Journal of World Business, Vol. 45 No. 3, pp. 257-265.

Manolova, T.S., Manev, I.M. and Gyoshev, B.S. (2014), "Friends with money? Owner's financial network and new venture internationalization in a transition economy", International Small Business Journal: Researching Entrepreneurship, Vol. 32 No. 8, pp. 944-966.

Martineau, C. and Pastoriza, D. (2016), "International involvement of established SMEs: a systematic review of antecedents, outcomes and moderators", International Business Review, Vol. 25 No. 2, pp. $458-470$.

Martin, S.L. and Javalgi, R.R.G. (2016), "Entrepreneurial orientation, marketing capabilities and performance: the moderating role of competitive intensity on Latin American international new ventures", Journal of Business Research, Vol. 69 No. 6, pp. 2040-2051.

Martin, S.L. and Javalgi, R.R.G. (2019), "Explaining performance determinants: a knowledge-based view of international new ventures", Journal of Business Research, Vol. 101, pp. 615-626.

Martin, S.L., Javalgi, R.G. and Cavusgil, E. (2017), "Marketing capabilities, positional advantage, and performance of born global SMEs: contingent effect of ambidextrous innovation”, International Business Review, Vol. 26 No. 3, pp. 527-543.

Martin, S.L., Javalgi, R.R.G. and Ciravegna, L. (2018), "Service advantage built on service capabilities: an empirical inquiry of international new ventures", Journal of Business Research, Vol. 88, pp. 371-381.

Masango, S. and Marinova, S. (2014), "Knowledge-based network ties in early rapidly internationalising small firms: a missing link?”, International Entrepreneurship and Management Journal, Vol. 10 No. 3, pp. 471-486.

Michailova, S. (2011), "Contextualizing in international business research: why do we need more of it and how can we be better at it?", Scandinavian Journal of Management, Vol. 27 No. 1, pp. 129-139.

Minniti, M. and Bygrave, W. (1999), "The microfoundations of entrepreneurship”, Entrepreneurship Theory and Practice, Vol. 23 No. 4, pp. 41-52.

Minniti, M. and Bygrave, W. (2001), "A dynamic model of entrepreneurial learning”, Entrepreneurship Theory and Practice, Vol. 25 No. 3, pp. 5-16.

Monferrer, D., Blesa, A. and Ripollés, M. (2015), "Born globals trough knowledge-based dynamic capabilities and network market orientation”, BRQ Business Research Quarterly, Vol. 18 No. 1, pp. 18-36.

Morgan, N.A., Vorhies, D.W. and Mason, C.H. (2009), "Market orientation, marketing capabilities, and firm performance", Strategic Management Journal, Vol. 30 No. 8, pp. 909-920.

Mort, G.S. and Weerawardena, J. (2006), "Networking capability and international entrepreneurship: how networks function in Australian born global SMEs", International Marketing Review, Vol. 23 No. 5, pp. 549-572. 
Mort, G.S., Weerawardena, J. and Liesch, P. (2012), "Advancing entrepreneurial marketing: evidence from born global SMEs", European Journal of Marketing, Vol. 46 Nos 3/4, pp. 542-561.

Mostafiz, M.I., Sambasivan, M. and Goh, S.K. (2019), "Measurement scale of international opportunity identification in early internationalization firms", Asia-Pacific Journal of Business Administration, Vol. 11 No. 2, pp. 131-145.

Muñoz-Bullón, F., Sánchez-Bueno, M.J. and Vos-Saz, A. (2015), "Nascent entrepreneurs' personality attributes and the international dimension of new ventures", International Entrepreneurship and Management Journal, Vol. 11 No. 3, pp. 473-492.

Newey, L.R. and Zahra, S.A. (2009), “The evolving firm: how dynamic and operating capabilities interact to enable entrepreneurship", British Journal of Management, Vol. 20, pp. 81-100.

Nguyen, Q.A. and Mort, G.S. (2020), "Conceptualizing organizational-level and microfoundational capabilities: an integrated view of born-globals' internationalization", International Entrepreneurship and Management Journal, pp. 1-23.

Nordman, E.R. and Melén, S. (2008), "The impact of different kinds of knowledge for the internationalization process of born globals in the biotech business", Journal of World Business, Vol. 43 No. 2, pp. 171-185.

North, D.C. (1990), Institutions, Institutional Change and Economic Performance, Harvard University Press, Cambridge, MA.

Nummela, N., Saarenketo, S. and Loane, S. (2016), "The dynamics of failure in international new ventures: a case study of finnish and Irish software companies", International Small Business Journal: Researching Entrepreneurship, Vol. 34 No. 1, pp. 51-69.

Nummela, N., Saarenketo, S. and Puumalainen, K. (2004), "Rapidly with a rifle or more slowly with a shotgun? Stretching the company boundaries of internationalising ICT firms", Journal of International Entrepreneurship, Vol. 2 No. 4, pp. 275-288.

O’Reilly, C.A., III,. And Tushman, M.L. (2008), "Ambidexterity as a dynamic capability: resolving the innovator's dilemma”, Research in Organizational Behavior, Vol. 28, pp. 185-206.

Odlin, D. and Benson-Rea, M. (2017), "Competing on the edge: implications of network position for internationalizing small-and medium-sized enterprises", International Business Review, Vol. 26 No. 4, pp. 736-748.

Odorici, V. and Presutti, M. (2013), "The entrepreneurial experience and strategic orientation of hightech born global start-ups: an analysis of novice and habitual entrepreneurs", Journal of International Entrepreneurship, Vol. 11 No. 3, pp. 268-291.

Oesterle, M.J. and Wolf, J. (2011), "50 Years of management international review and IB/IM research", Management International Review, Vol. 51 No. 6, pp. 735-754.

Oviatt, B.M. and McDougall, P.P. (1994), "Toward a theory of international new ventures”, Journal of International Business Studies, Vol. 25 No. 1, pp. 45-64.

Oxtorp, L.A. (2014), "Dynamic managerial capability of technology-based international new ventures a basis for their long-term competitive advantage", Journal of International Entrepreneurship, Vol. 12 No. 4, pp. 389-420.

Øyna, S. and Alon, I. (2018), "A review of born globals", International Studies of Management and Organization, Vol. 48 No. 2, pp. 157-180.

Parker, H. and Ameen, K. (2018), "The role of resilience capabilities in shaping how SMEs respond to disruptions", Journal of Business Research, Vol. 88, pp. 535-541.

Park, S., LiPuma, J. and Prange, C. (2015), "Venture capitalist and entrepreneur knowledge of new venture internationalization: a review of knowledge components", International Small Business Journal: Researching Entrepreneurship, Vol. 33 No. 8, pp. 901-928.

Park, T. and Rhee, J. (2012), "Antecedents of knowledge competency and performance in born globals: the moderating effects of absorptive capacity", Management Decision, Vol. 50 No. 8, pp. $1361-1381$. 
Paul, J. and Rosado-Serrano, A. (2019), "Gradual internationalization vs born-global/international new venture models”, International Marketing Review, Vol. 36 No. 6, pp. 830-858.

Pehrsson, T., Ghannad, N., Pehrsson, A., Abt, T., Chen, S., Erath, F. and Hammarstig, T. (2015), "Dynamic capabilities and performance in foreign markets: developments within international new ventures", Journal of International Entrepreneurship, Vol. 13 No. 1, pp. 28-48.

Peiris, I.K., Akoorie, M.E. and Sinha, P. (2012), "International entrepreneurship: a critical analysis of studies in the past two decades and future directions for research", Journal of International Entrepreneurship, Vol. 10 No. 4, pp. 279-324.

Pellegrino, J.M. and McNaughton, R.B. (2017), "Beyond learning by experience: the use of alternative learning processes by incrementally and rapidly internationalizing SMEs", International Business Review, Vol. 26 No. 4, pp. 614-627.

Peters, M.D., Godfrey, C.M., Khalil, H., McInerney, P., Parker, D. and Soares, C.B. (2015), "Guidance for conducting systematic scoping reviews", International Journal of Evidence-Based Healthcare, Vol. 13 No. 3, pp. 141-146.

Peterson, J., Pearce, P.F., Ferguson, L.A. and Langford, C.A. (2017), "Understanding scoping reviews: definition, purpose, and process", Journal of the American Association of Nurse Practitioners, Vol. 29 No. 1, pp. 12-16.

Pinho, J.C. and Prange, C. (2016), "The effect of social networks and dynamic internationalization capabilities on international performance", Journal of World Business, Vol. 51 No. 3, pp. 391-403.

Prashantham, S. (2005), "Toward a knowledge-based conceptualization of internationalization”, Journal of International Entrepreneurship, Vol. 3 No. 1, pp. 37-52.

Prashantham, S. and Birkinshaw, J. (2015), "Choose your friends carefully: home-country ties and new venture internationalization", Management International Review, Vol. 55 No. 2, pp. 207-234.

Prashantham, S. and Dhanaraj, C. (2010), "The dynamic influence of social capital on the international growth of new ventures", Journal of Management Studies, Vol. 47 No. 6, pp. 967-994.

Prashantham, S. and Dhanaraj, C. (2015), "MNE ties and new venture internationalization: exploratory insights from India", Asia Pacific Journal of Management, Vol. 32 No. 4, pp. 901-924.

Prashantham, S. and Floyd, S.W. (2012), "Routine microprocesses and capability learning in international new ventures", Journal of International Business Studies, Vol. 43 No. 6, pp. 544-562.

Prashantham, S. and Floyd, S.W. (2019), "Navigating liminality in new venture internationalization", Journal of Business Venturing, Vol. 34 No. 3, pp. 513-527.

Prashantham, S. and Young, S. (2011), "Post-entry speed of international new ventures", Entrepreneurship Theory and Practice, Vol. 35 No. 2, pp. 275-292.

Prashantham, S., Kumar, K., Bhagavatula, S. and Sarasvathy, S.D. (2019), "Effectuation, networkbuilding, and internationalization speed", International Small Business Journal: Researching Entrepreneurship, Vol. 37 No. 1, pp. 3-21.

Prieto-Sánchez, C.J. and Merino, F. (2021), "Incidence of cultural, economic, and environmental factors in the emergence of born-global companies in Latin America", Global Strategy Journal, pp. 1-28, doi: $10.1002 /$ gsj.1398.

Rasmussan, E.S., Koed Madsen, T. and Evangelista, F. (2001), "The founding of the born global company in Denmark and Australia: sensemaking and networking", Asia Pacific Journal of Marketing and Logistics, Vol. 13 No. 3, pp. 75-107.

Reay, T., Berta, W. and Kohn, M.K. (2009), "What's the evidence on evidence-based management?", Academy of Management Perspectives, Vol. 23 No. 4, pp. 5-18.

Rennie, M.W. (1993), “Born global”, The McKinsey Quarterly, Vol. 4, pp. 45-53. 
Reuber, A.R., Dimitratos, P. and Kuivalainen, O. (2017), "Beyond categorization: new directions for theory development about entrepreneurial internationalization", Journal of International Business Studies, Vol. 48 No. 4, pp. 411-422.

Rialp, A., Rialp, J. and Knight, G.A. (2005a), "The phenomenon of early internationalizing SMEs: what do we know after a decade (1993-2003) of scientific inquiry?", International Business Review, Vol. 14 No. 2, pp. 147-166.

Rialp, A., Rialp, J., Urbano, D. and Vaillant, Y. (2005b), “The born-global phenomenon: a comparative case study research", Journal of International Entrepreneurship, Vol. 3 No. 2, pp. 133-171.

Ripollés, M. and Blesa, A. (2012), "International new ventures as 'small multinationals': the importance of marketing capabilities", Journal of World Business, Vol. 47 No. 2, pp. 277-287.

Ripollés, M., Blesa, A. and Monferrer, D. (2012), "Factors enhancing the choice of higher resource commitment entry modes in international new ventures", International Business Review, Vol. 21 No. 4, pp. 648-666.

Ripollés-Meliá, M., Menguzzato-Boulard, M. and Sánchez-Peinado, L. (2007), "Entrepreneurial orientation and international commitment", Journal of International Entrepreneurship, Vol. 5 No. 3, pp. $65-83$.

Rodríguez-Ruiz, F., Almodóvar, P. and Nguyen, Q.T. (2019), "Intellectual structure of international new venture research”, Multinational Business Review, Vol. 27 No. 4, pp. 285-316.

Rodríguez-Serrano, M.Á. and Martín-Armario, E. (2019), "Born-global SMEs, performance, and dynamic absorptive capacity: evidence from Spanish SMEs", Journal of Small Business Management, Vol. 57 No. 2, pp. 298-326.

Rodríguez-Serrano, M.Á. and Martín-Velicia, F.A. (2015), "The role of absorptive capability on bornglobal performance", Journal of Promotion Management, Vol. 21 No. 4, pp. 447-458.

Romanello, R. and Chiarvesio, M. (2017), "Turning point: when born globals enter post-entry stage", Journal of International Entrepreneurship, Vol. 15 No. 2, pp. 177-206.

Romanello, R. and Chiarvesio, M. (2019), "Early internationalizing SMEs: 2004-2018", Journal of International Entrepreneurship, Vol. 17 No. 2, pp. 172-219.

Rousseau, D.M., Manning, J. and Denyer, D. (2008), "Evidence in management and organizational science: assembling the field's full weight of scientific knowledge through syntheses", Academy of Management Annals, Vol. 2 No. 1, pp. 475-515.

Sandberg, J. and Alvesson, M. (2011), "Ways of constructing research questions: gap-spotting or problematization?", Organization, Vol. 18 No. 1, pp. 23-44.

Sapienza, H.J., Autio, E., George, G. and Zahra, S.A. (2006), "A capabilities perspective on the effects of early internationalization on firm survival and growth", Academy of Management Review, Vol. 31 No. 4, pp. 914-933.

Schmidt, H.M. and Santamaria-Alvarez, S.M. (2021), "Routines in international business: a semisystematic review of the concept", Journal of International Management, p. 100878, doi: 10.1016/ j.intman.2021.100878.

Schwens, C. and Kabst, R. (2011), "Entry learning, age at internationalization, and foreign-venture performance of young technology firms”, Schmalenbach Business Review, Vol. 63, pp. 308-330.

Schwens, C., Zapkau, F.B., Bierwerth, M., Isidor, R., Knight, G. and Kabst, R. (2018), "International entrepreneurship: a meta-analysis on the internationalization and performance relationship", Entrepreneurship Theory and Practice, Vol. 42 No. 5, pp.734-768.

Sedziniauskiene, R., Sekliuckiene, J. and Zucchella, A. (2019), "Networks' impact on the entrepreneurial internationalization: a literature review and research agenda", Management International Review, Vol. 59 No. 5, pp. 779-823.

Sepulveda, F. and Gabrielsson, M. (2013), "Network development and firm growth: a resource-based study of B2B born globals", Industrial Marketing Management, Vol. 42 No. 5, pp. 792-804. 
Servantie, V., Cabrol, M., Guieu, G. and Boissin, J.P. (2016), "Is international entrepreneurship a field? A bibliometric analysis of the literature (1989-2015)", Journal of International Entrepreneurship, Vol. 14 No. 2, pp. 168-212.

Sharma, D.D. and Blomstermo, A. (2003), "The internationalization process of born globals: a network view", International Business Review, Vol. 12 No. 6, pp. 739-753.

Sinkovics, N., Sinkovics, R.R. and Yamin, M. (2014), "The role of social value creation in business model formulation at the bottom of the pyramid-implications for MNEs?", International Business Review, Vol. 23 No. 4, pp. 692-707.

Snow, C.C. and Hrebiniak, L.G. (1980), "Strategy, distinctive competence, and organizational performance", Administrative Science Quarterly, Vol. 25 No. 2, pp. 317-336.

Spence, M. and Crick, D. (2009), "An exploratory study of Canadian international new venture firms' development in overseas markets", Qualitative Market Research, Vol. 12 No. 2, pp. 208-233.

Spence, M., Orser, B. and Riding, A. (2011), “A comparative study of international and domestic new ventures”, Management International Review, Vol. 51 No. 1, pp. 3-21.

Stayton, J. and Mangematin, V. (2016), "Startup time, innovation and organizational emergence: a study of USA-based international technology ventures", Journal of International Entrepreneurship, Vol. 14 No. 3, pp. 373-409.

Svensson, G. (2006), "The paradoxnoia of top journal(s) in marketing”, European Journal of Marketing, Vol. 40 Nos 11/12, pp. 1153-1168.

Svensson, G. and Payan, J.M. (2009), "Organizations that are international from inception: terminology and research constellations - 'academic protectionism' or 'academic myopia?”, Journal of Small Business and Enterprise Development, Vol. 16 No. 3, pp. 406-417.

Svensson, G. and Wood, G. (2006), "The pareto plus syndrome in top marketing journals: research and journal criteria”, European Business Review, Vol. 18 No. 6, pp. 457-467.

Tallman, S. and Fladmoe-Lindquist, K. (2002), "Internationalization, globalization, and capability-based strategy”, California Management Review, Vol. 45 No. 1, pp. 116-135.

Tang, Y.K. (2006), "Managing the strengths of ties for internationalization: lessons from four rapidly internationalized Chinese SMEs", Journal of Asia Business Studies, Vol. 1 No. 1, pp. 54-64.

Taylor, M. and Jack, R. (2013), "Understanding the pace, scale and pattern of firm internationalization: an extension of the 'born global' concept", International Small Business Journal, Vol. 31 No. 6, pp. 701-721.

Teece, D.J. (2007), "Explicating dynamic capabilities: the nature and microfoundations of (sustainable) enterprise performance”, Strategic Management Journal, Vol. 28 No. 13, pp. 1319-1350.

Teece, D.J., Pisano, G. and Shuen, A. (1997), "Dynamic capabilities and strategic management", Strategic Management Journal, Vol. 18 No. 7, pp. 509-533.

Thai, M.T.T. and Chong, L.C. (2008), "Born-global: the case of four Vietnamese SMEs", Journal of International Entrepreneurship, Vol. 6 No. 2, pp. 72-100.

Thistoll, T. and Pauleen, D. (2010), "Commercialising innovation internationally: a case study of social network and relationship management", Journal of International Entrepreneurship, Vol. 8 No. 1, pp. 36-54.

Thukral, S. and Jain, A. (2021), "Unveiling contemporary dimensions in the internationalization of family firms through bibliometric analysis and thematic analysis", Review of International Business and Strategy, Vol. 31 No. 4, doi: 10.1108/RIBS-09-2020-0121.

Tolstoy, D. and Agndal, H. (2010), "Network resource combinations in the international venturing of small biotech SMEs", Technovation, Vol. 30 No. 1, pp. 24-36. 
Torkkeli, L., Puumalainen, K., Saarenketo, S. and Kuivalainen, O. (2012), "The effect of network competence and environmental hostility on the internationalization of SMEs", Journal of International Entrepreneurship, Vol. 10 No. 1, pp. 25-49.

Review and synthesis

Torraco, R.J. (2005), "Writing integrative literature reviews: guidelines and examples", Human Resource Development Review, Vol. 4 No. 3, pp. 356-367.

Tranfield, D., Denyer, D. and Smart, P. (2003), "Towards a methodology for developing evidenceinformed management knowledge by means of systematic review", British Journal of Management, Vol. 14 No. 3, pp. 207-222.

Tsui, A.S. (2004), "Contributing to global management knowledge: a case for high quality indigenous research", Asia Pacific Journal of Management, Vol. 21 No. 4, pp. 491-513.

Tsui, A.S. (2007), "From homogenization to pluralism: international management research in the academy and beyond", Academy of Management Journal, Vol. 50 No. 6, pp. 1353-1364.

Tuomisalo, T. and Leppäaho, T. (2018), "Learning in international new ventures: a systematic review", International Business Review, Vol. 28 No. 3, pp. 463-481.

Vapola, T.J., Tossavainen, P. and Gabrielsson, M. (2008), "The battleship strategy: the complementing role of born globals in MNC's new opportunity creation", Journal of International Entrepreneurship, Vol. 6 No. 1, pp. 1-21.

Varma, S., Nayyar, R. and Bansal, V. (2016), "What drives precocity? A study of Indian technologyintensive SMEs”, Journal of East-West Business, Vol. 22 No. 4, pp. 242-269.

Verbeke, A. and Ciravegna, L. (2018), "International entrepreneurship research versus international business research: a false dichotomy?”, Journal of International Business Studies, Vol. 49 No. 4, pp. 387-394.

Verreynne, M.L., Hine, D., Coote, L. and Parker, R. (2016), "Building a scale for dynamic learning capabilities: the role of resources, learning, competitive intent and routine patterning", Journal of Business Research, Vol. 69 No. 10, pp. 4287-4303.

Vissak, T. (2007), "The emergence and success factors of fast internationalizers: four cases from Estonia", Journal of East-West Business, Vol. 13 No. 1, pp. 11-33.

Voudouris, I., Dimitratos, P. and Salavou, H. (2011), "Entrepreneurial learning in the international new high-technology venture", International Small Business Journal: Researching Entrepreneurship, Vol. 29 No. 3, pp. 238-258.

Weerawardena, J., Mort, G.S. and Liesch, P.W. (2019a), "Capabilities development and deployment activities in born global B-to-B SMEs for early entry into international markets", Industrial Marketing Management, Vol. 78, pp. 122-136.

Weerawardena, J., Salunke, S., Knight, G., Mort, G.S. and Liesch, P.W. (2019b), "The learning subsystem interplay in service innovation in born global service firm internationalization", Industrial Marketing Management, doi: 10.1016/j.indmarman.2019.05.012.

Weerawardena, J., Mort, G.S., Liesch, P.W. and Knight, G. (2007), "Conceptualizing accelerated internationalization in the born global firm: a dynamic capabilities perspective", Journal of World Business, Vol. 42 No. 3, pp. 294-306.

Weerawardena, J., Mort, G.S., Salunke, S., Knight, G. and Liesch, P.W. (2015), "The role of the market Sub-system and the socio-technical Sub-system in innovation and firm performance: a dynamic capabilities approach", Journal of the Academy of Marketing Science, Vol. 43 No. 2, pp. 221-239.

Wehner, M.C., Schwens, C. and Kabst, R. (2015), "Individual-level experience and organizational-level absorptive capacity: the special case of international new ventures", Journal of Business Economics, Vol. 85 No. 5, pp. 545-568.

Wernerfelt, B. (1984), "A resource-based view of the firm”, Strategic Management Journal, Vol. 5 No. 2, pp. $171-180$.

Winter, S.G. (2003), "Understanding dynamic capabilities", Strategic Management Journal, Vol. 24 No. 10, pp. 991-995. 
Yu, J., Gilbert, B.A. and Oviatt, B.M. (2011), "Effects of alliances, time, and network cohesion on the initiation of foreign sales by new ventures", Strategic Management Journal, Vol. 32 No. 4, pp. 424-446.

Zahra, S.A. (2005), "A theory of international new ventures: a decade of research", Journal of International Business Studies, Vol. 36 No. 1, pp. 20-28.

Zahra, S.A., Abdelgawad, S.G. and Tsang, E.W. (2011), "Emerging multinationals venturing into developed economies: implications for learning, unlearning, and entrepreneurial capability", Journal of Management Inquiry, Vol. 20 No. 3, pp. 323-330.

Zahra, S.A. and George, G. (2002), "International entrepreneurship: the current status of the field and future research agenda", Strategic Entrepreneurship: Creating a New Mindset, pp. 255-288.

Zahra, S.A., Ireland, R.D. and Hitt, M.A. (2000), "International expansion by new venture SMEs: international diversity, mode of market entry, technological learning, and performance", Academy of Management Journal, Vol. 43 No. 5, pp. 925-950.

Zahra, S.A., Korri, J.S. and Yu, J. (2005), “Cognition and international entrepreneurship: implications for research on international opportunity recognition and exploitation", International Business Review, Vol. 14 No. 2, pp. 129-146.

Zahra, S.A., Matherne, B.P. and Carleton, J.M. (2003), "Technological resource leveraging and the internationalization of new ventures", Journal of International Entrepreneurship, Vol. 1 No. 2, pp. 163-186.

Zalan, T. (2018), "Born global on blockchain”, Review of International Business and Strategy, Vol. 28 No. 1, pp. 19-34.

Zettinig, P. and Benson-Rea, M. (2008), "What becomes of international new ventures? A co-evolutionary approach”, European Management Journal, Vol. 26 No. 6, pp. 354-365.

Zhang, M., Gao, Q. and Cho, H.S. (2017), "The effect of Sub-national institutions and international entrepreneurial capability on international performance of export-focused SMEs: evidence from China and South Korea", Journal of International Entrepreneurship, Vol. 15 No. 1, pp. 85-110.

Zhang, M., Sarker, S. and Sarker, S. (2013), "Drivers and export performance impacts of IT capability in 'born-global' SMEs: a cross-national study”, Information Systems Journal, Vol. 23 No. 5, pp. 419-443.

Zhang, M. and Tansuhaj, P. (2007), "Organizational culture, information technology capability, and performance: the case of born global SMEs", Multinational Business Review, Vol. 15 No. 3, pp. 43-77.

Zhang, M., Tansuhaj, P. and McCullough, J. (2009), "International entrepreneurial capability: the measurement and a comparison between born global SMEs and traditional exporters in China", Journal of International Entrepreneurship, Vol. 7 No. 4, pp. 292-322.

Zhou, L. (2007), "The effects of entrepreneurial proclivity and foreign market knowledge on early internationalization", Journal of World Business, Vol. 42 No. 3, pp. 281-293.

Zhou, L., Barnes, B.R. and Lu, Y. (2010), "Entrepreneurial precocity, capability upgrading, and performance advantage of newness among international new ventures", Journal of International Business Studies, Vol. 41 No. 5, pp. 882-905.

Zhou, L., Wu, A. and Barnes, B.R. (2012), "The effects of early internationalization on performance outcomes in young international ventures: the mediating role of marketing capabilities", Journal of International Marketing, Vol. 20 No. 4, pp. 25-45.

Zolin, R. and Schlosser, F. (2013), "Characteristics of immigrant entrepreneurs and their involvement in international new ventures", Thunderbird International Business Review, Vol. 55 No. 3, pp. 271-284. 


\section{Further reading}

Cohen, W.M. and Levinthal, D.A. (1990), "Absorptive capacity: a new perspective on learning and innovation”, Administrative Science Quarterly, Vol. 35 No. 1, pp. 128-152.

Crick, D. and Crick, J. (2015), "Learning and decision making in marketing planning: a study of New Zealand vineyards", Marketing Intelligence and Planning, Vol. 33 No. 5, pp. 707-732, doi: 10.1108/MIP-08-2014-0144.

DeSarbo, W.S., Anthony Di Benedetto, C., Song, M. and Sinha, I. (2005), "Revisiting the miles and snow strategic framework: uncovering interrelationships between strategic types, capabilities, environmental uncertainty, and firm performance", Strategic Management Journal, Vol. 26 No. 1, pp. $47-74$.

Eisenhardt, K.M. and Martin, J.A. (2000), "Dynamic capabilities: what are they?", Strategic Management Journal, Vol. 21 No. 10-11, pp. 1105-1121.

Felin, T., Foss, N.J. and Ployhart, R.E. (2015), "The microfoundations movement in strategy and organization theory", Academy of Management Annals, Vol. 9 No. 1, pp. 575-632.

Gavetti, G. (2005), "Cognition and hierarchy: rethinking the microfoundations of capabilities' development”, Organization Science, Vol. 16 No. 6, pp. 599-617.

Gibson, C.B. and Birkinshaw, J. (2004), "The antecedents, consequences, and mediating role of organizational ambidexterity", Academy of Management Journal, Vol. 47 No. 2, pp. 209-226.

Helfat, C.E. and Peteraf, M.A. (2015), "Managerial cognitive capabilities and the microfoundations of dynamic capabilities", Strategic Management Journal, Vol. 36 No. 6, pp. 831-850.

Hessels, J. and Terjesen, S. (2010), "Resource dependency and institutional theory perspectives on direct and indirect export choices", Small Business Economics, Vol. 34 No. 2, pp. 203-220.

Jones, O. and Gatrell, C. (2014), "The future of writing and reviewing for IJMR", International Journal of Management Reviews, Vol. 16 No. 3, pp. 249-264.

Kump, B., Engelmann, A., Kessler, A. and Schweiger, C. (2019), "Toward a dynamic capabilities scale: measuring organizational sensing, seizing, and transforming capacities", Industrial and Corporate Change, Vol. 28 No. 5, pp. 1149-1172.

Laufs, K. and Schwens, C. (2014), "Foreign market entry mode choice of small and medium-sized enterprises: a systematic review and future research agenda", International Business Review, Vol. 23 No. 6, pp. 1109-1126.

Leonidou, L.C., Palihawadana, D. and Theodosiou, M. (2011), "National export-promotion programs as drivers of organizational resources and capabilities: effects on strategy, competitive advantage, and performance", Journal of International Marketing, Vol. 19 No. 2, pp. 1-29.

O'Reilly, C.A., III,. And Tushman, M.L. (2013), "Organizational ambidexterity: past, present, and future", Academy of Management Perspectives, Vol. 27 No. 4, pp. 324-338.

Paul, J. and Feliciano-Cestero, M.M. (2020), "Five decades of research on foreign direct investment by MNEs: an overview and research agenda", Journal of Business Research, Vol. 124, pp. 800-812.

Pellegrino, J.M. and McNaughton, R.B. (2015), "The co-evolution of learning and internationalization strategy in international new ventures", Management International Review, Vol. 55 No. 4, pp. $457-483$.

Ribeiro, J. and Forte, R. (2019), "Fifty years of literature on export assistance programmes: a bibliometric analysis", Global Economy Journal, Vol. 19 No. 4, pp. 1-29.

Wang, C.L. and Ahmed, P.K. (2007), "Dynamic capabilities: a review and research agenda", International Journal of Management Reviews, Vol. 9 No. 1, pp. 31-51.

Zahra, S.A., Sapienza, H.J. and Davidsson, P. (2006), "Entrepreneurship and dynamic capabilities: a review, model and research agenda", Journal of Management Studies, Vol. 43 No. 4, pp. 917-955.
Review and synthesis

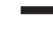


RIBS

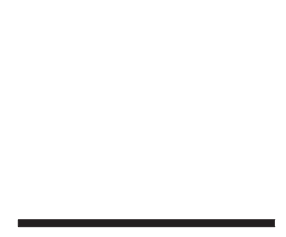

\section{Appendix 1}

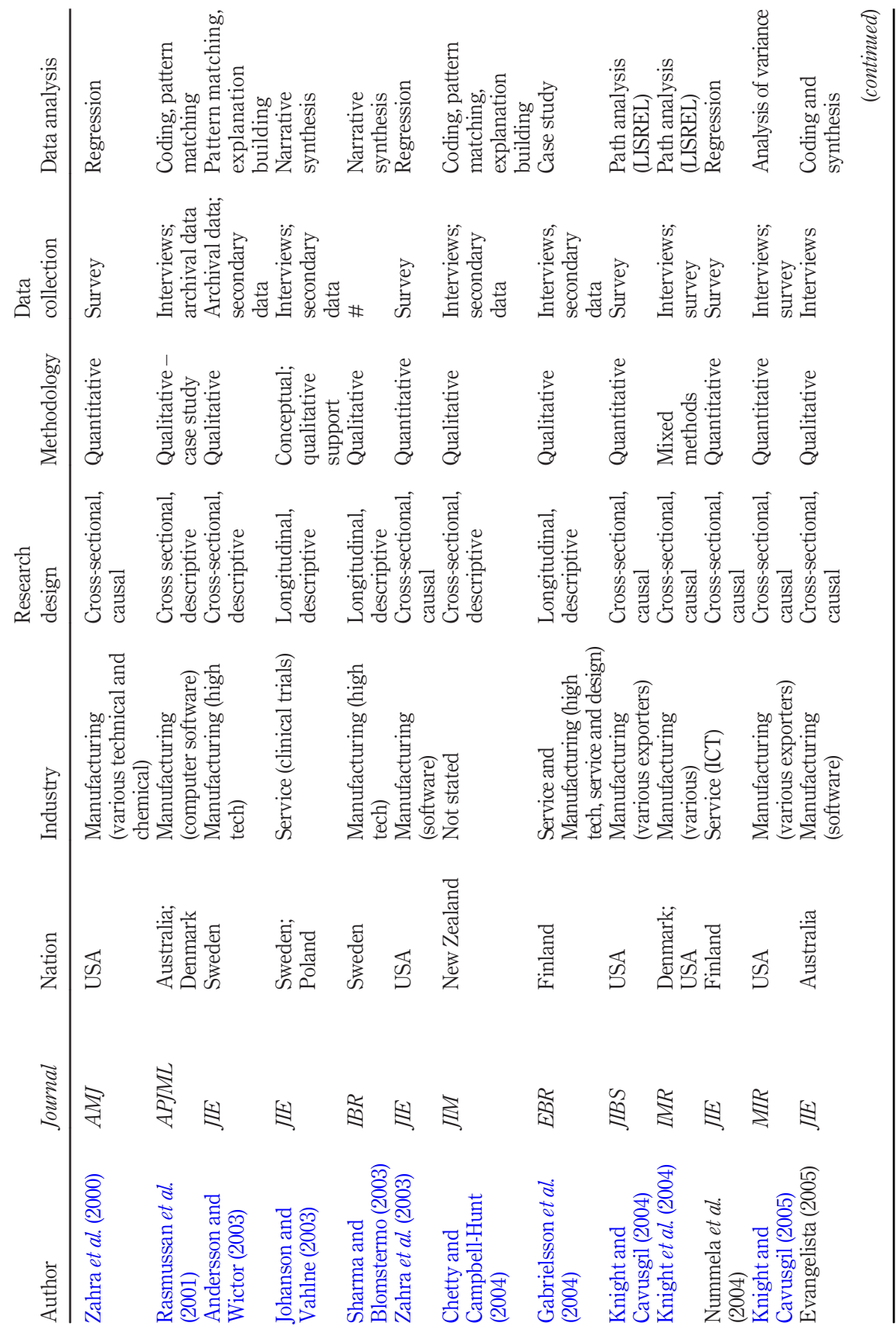

Table A1.

Research design and methods

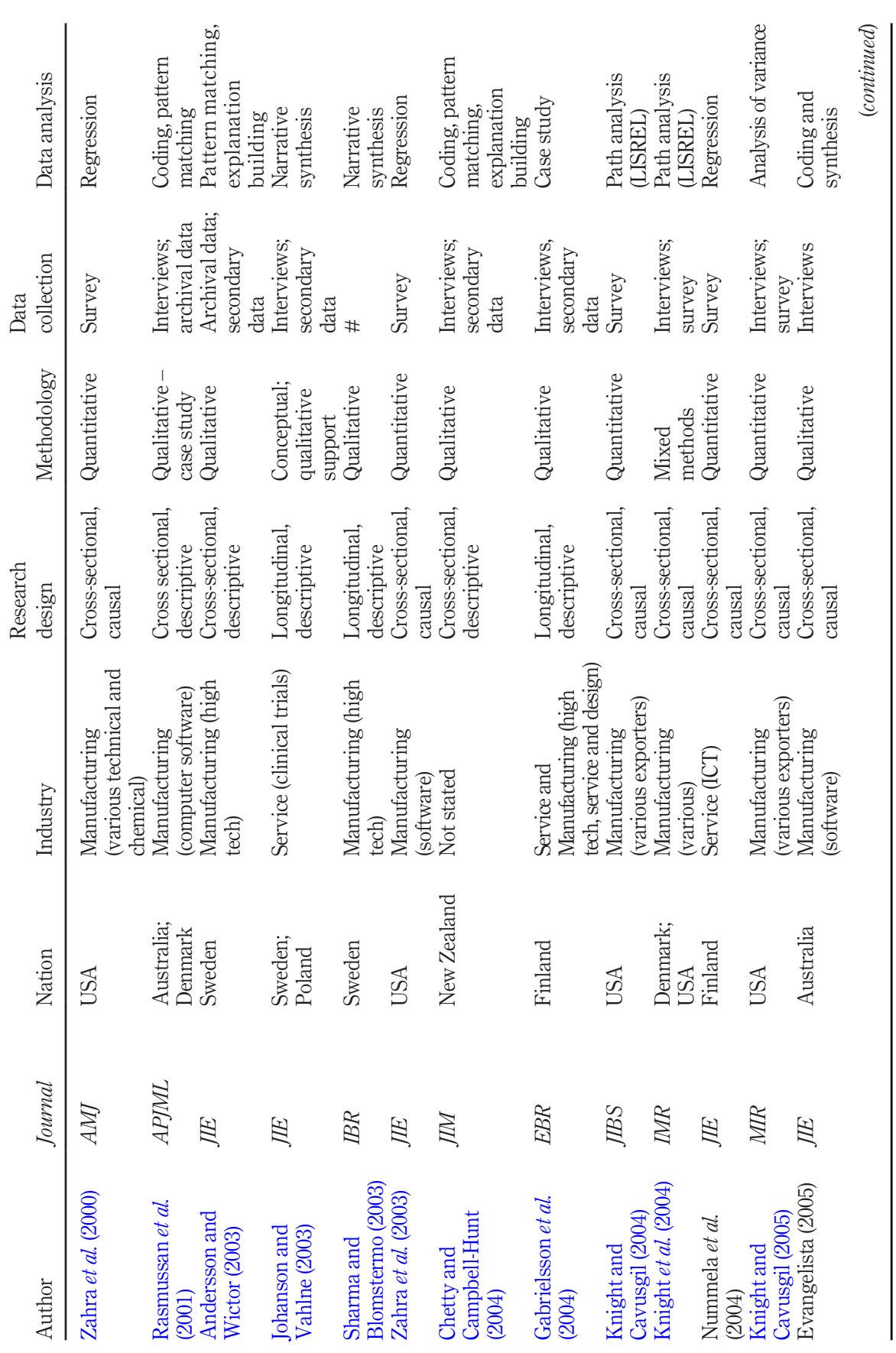


Review and

synthesis

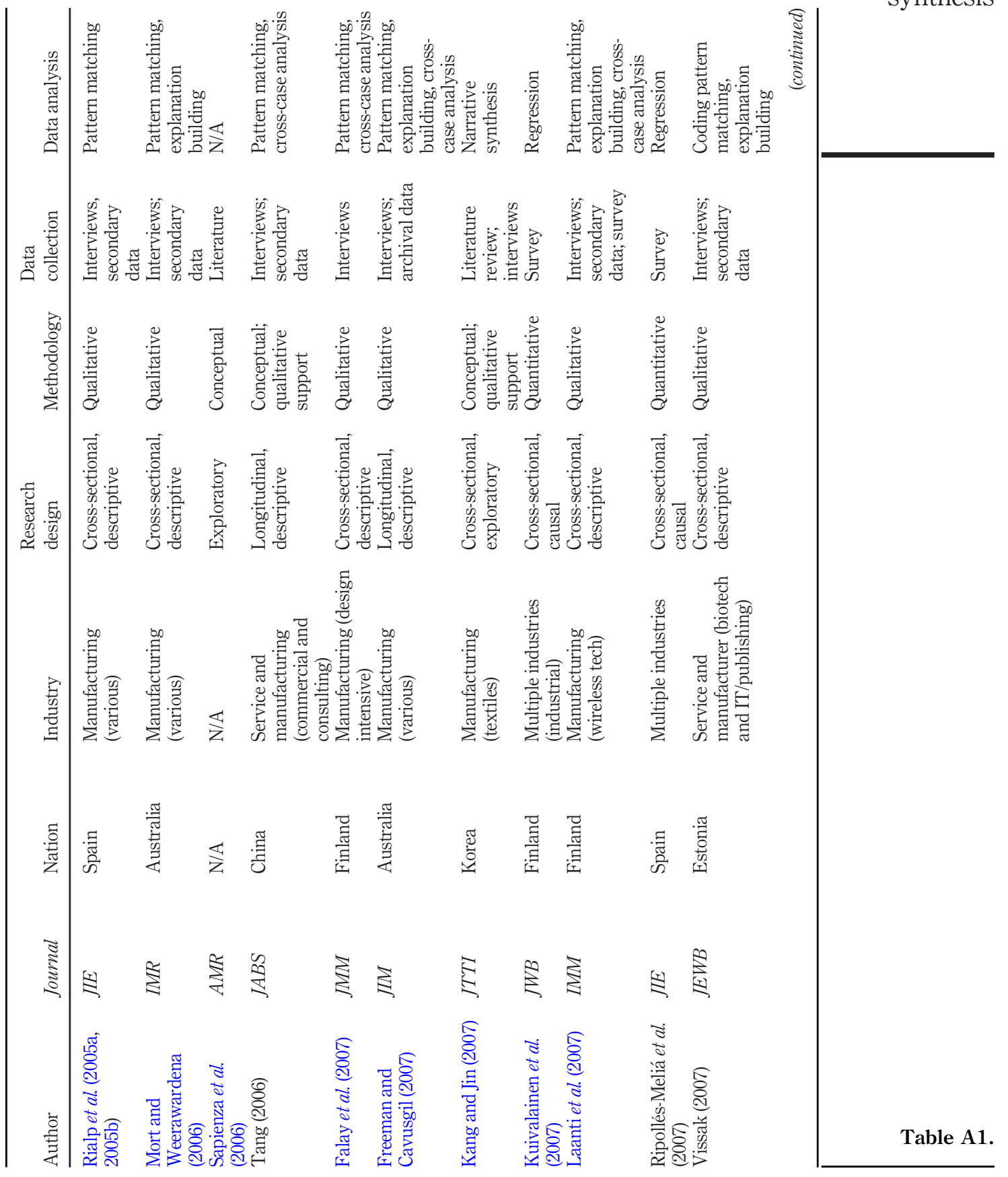




\section{RIBS}

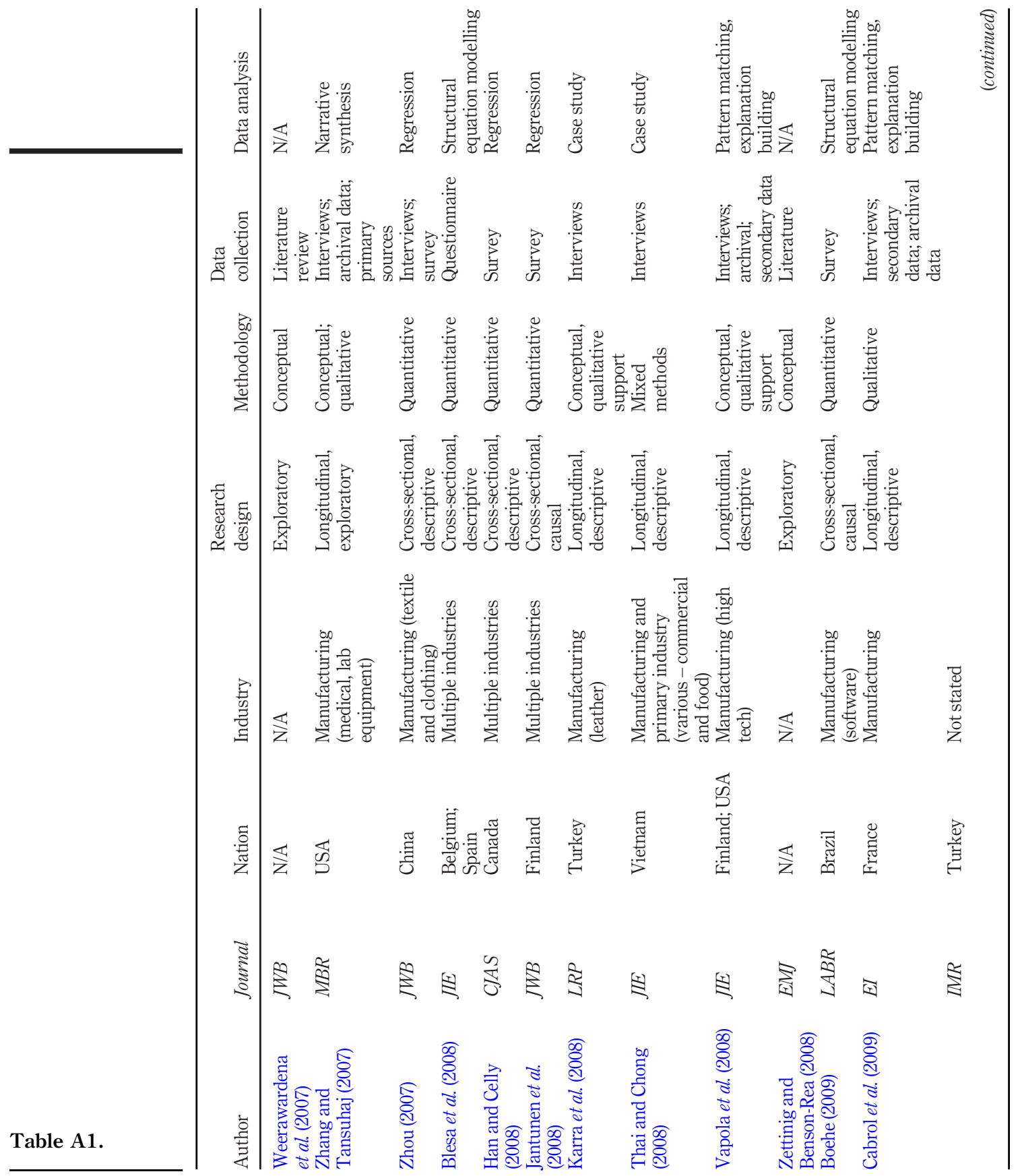


Review and

synthesis

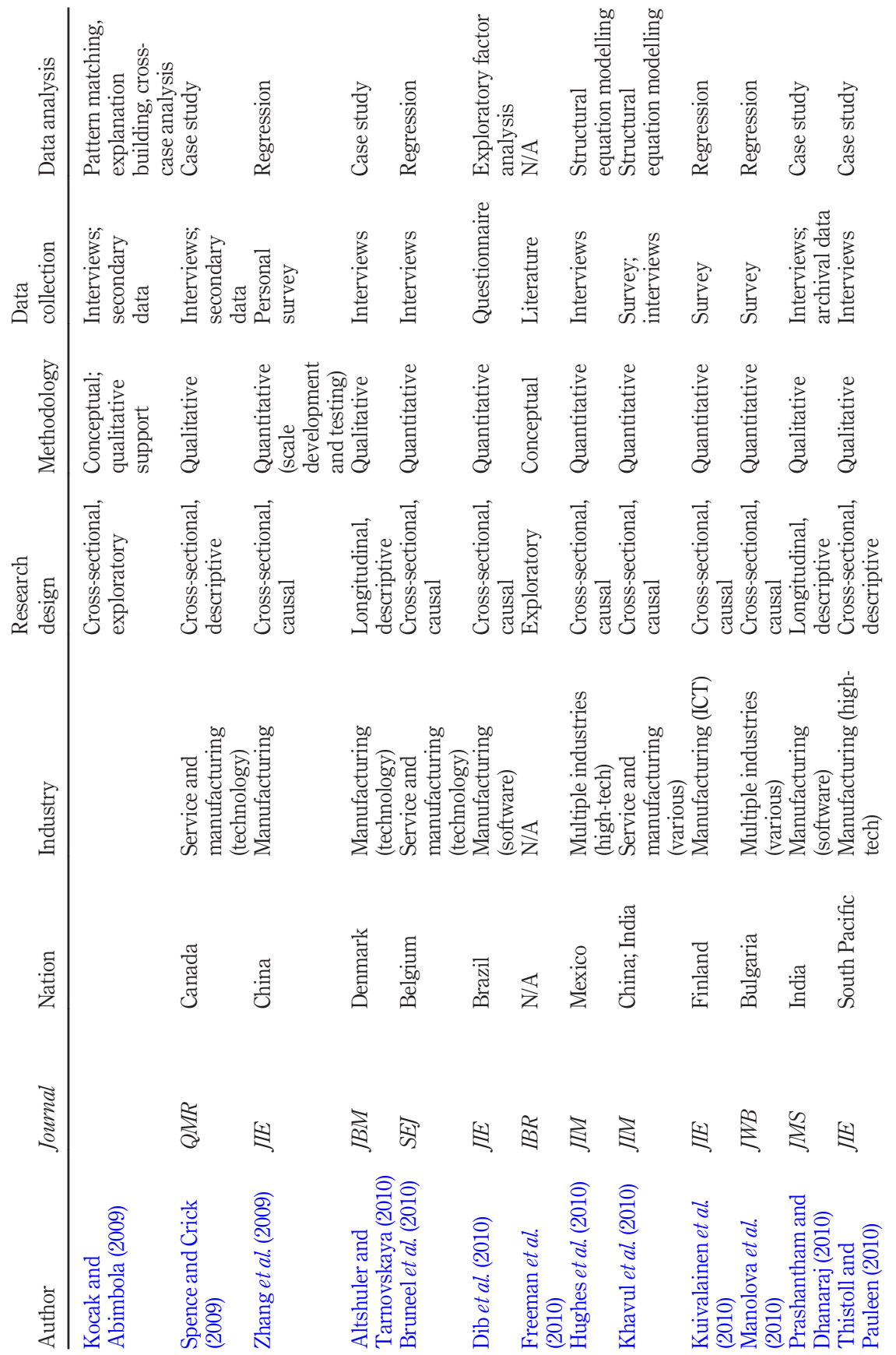

Table A1. 


\section{RIBS}

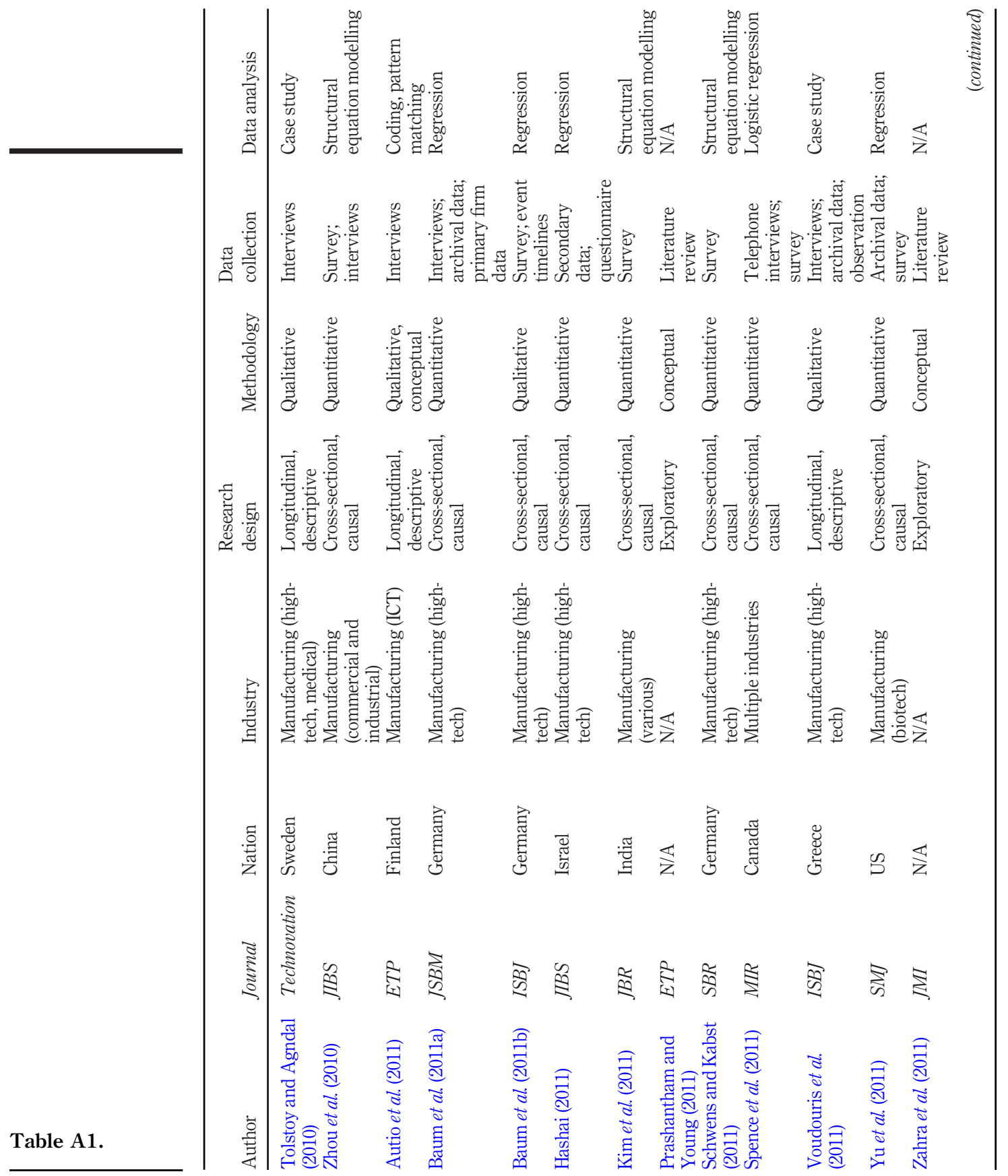


Review and

synthesis

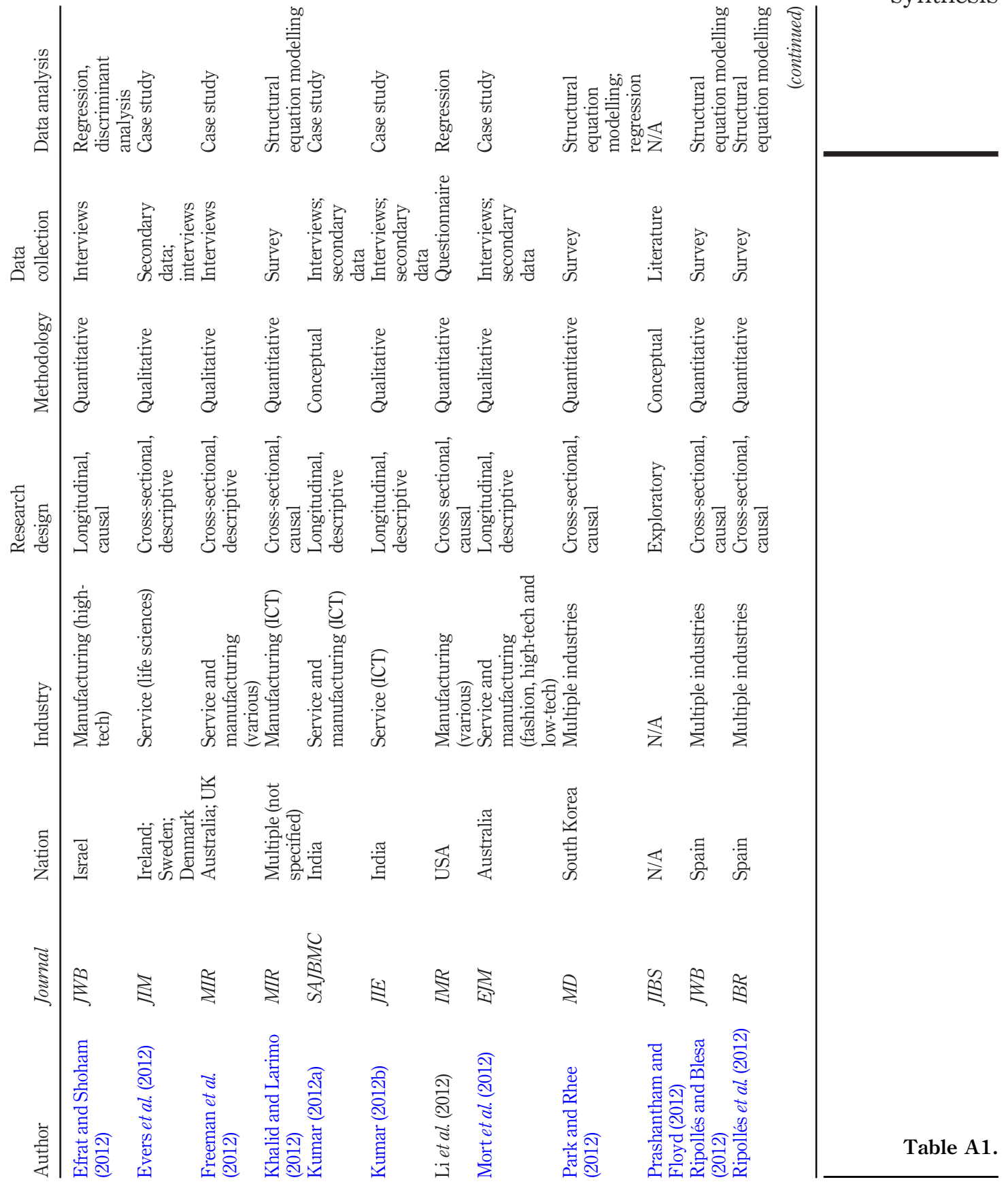




\section{RIBS}

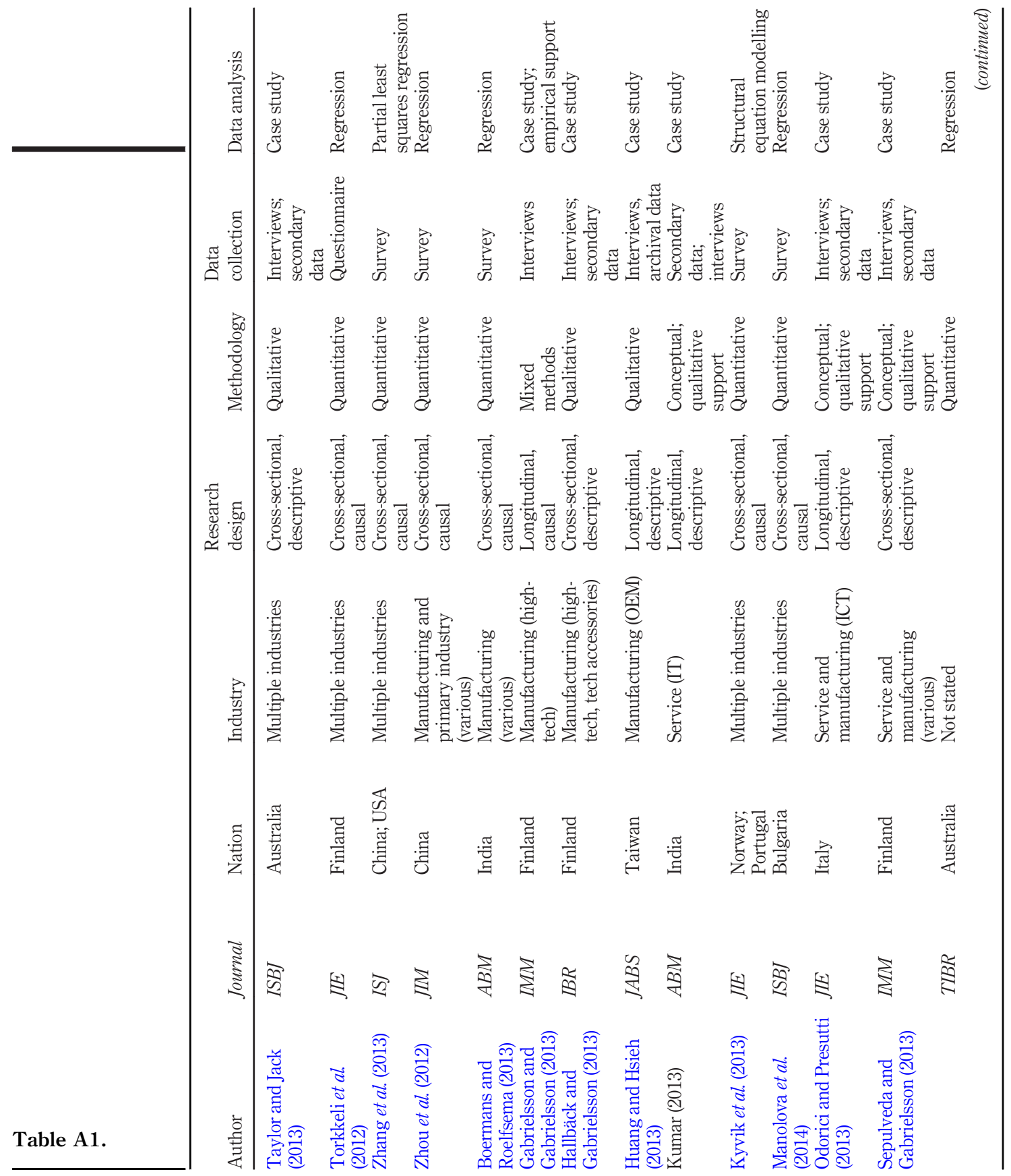


Review and

synthesis

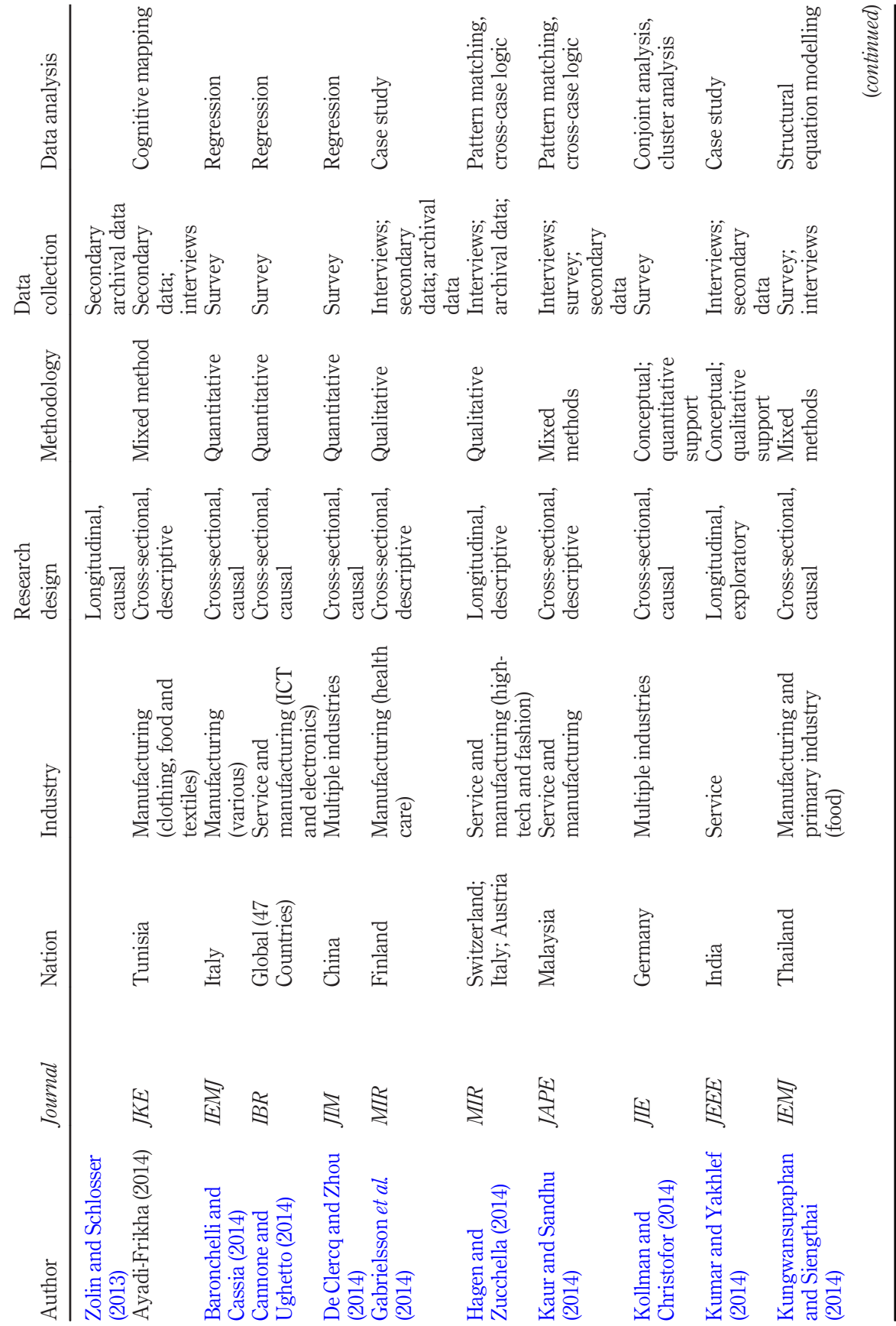

Table A1. 


\section{RIBS}

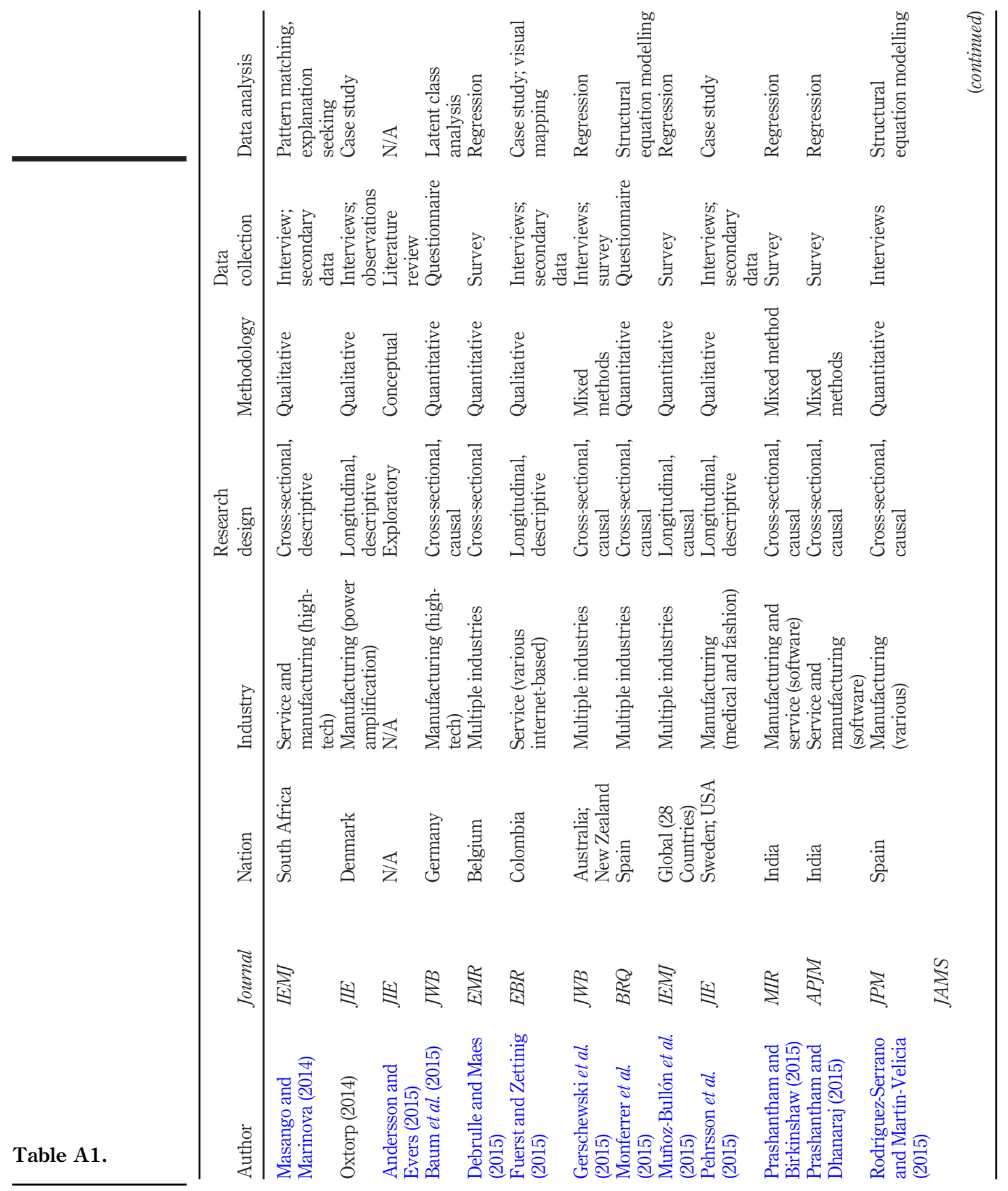


Review and

synthesis

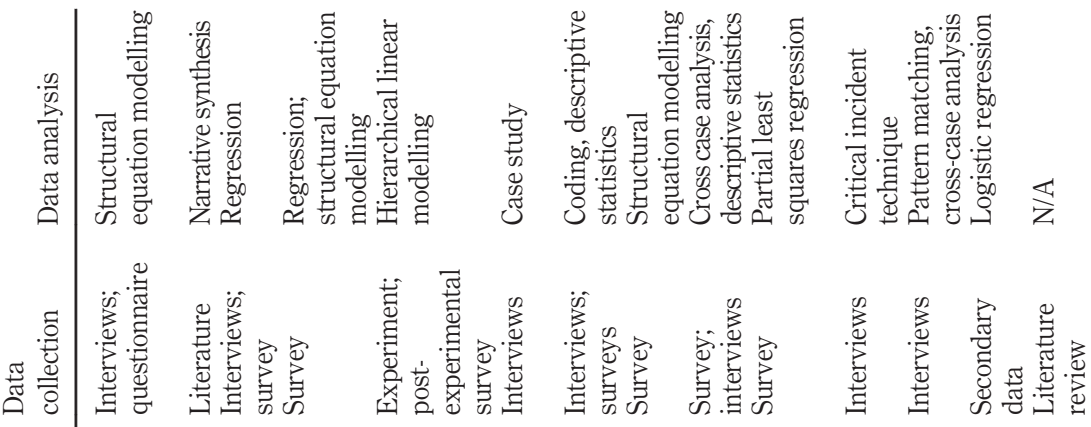

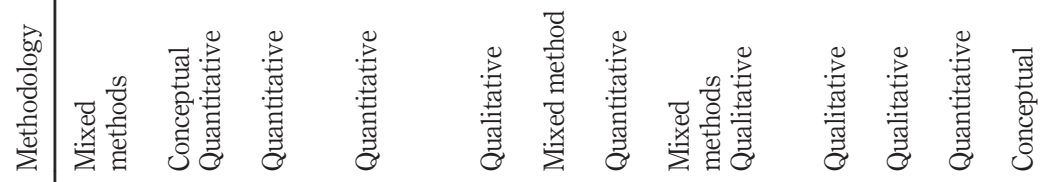

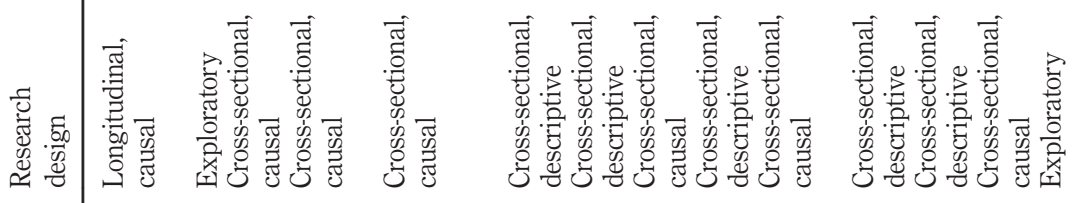

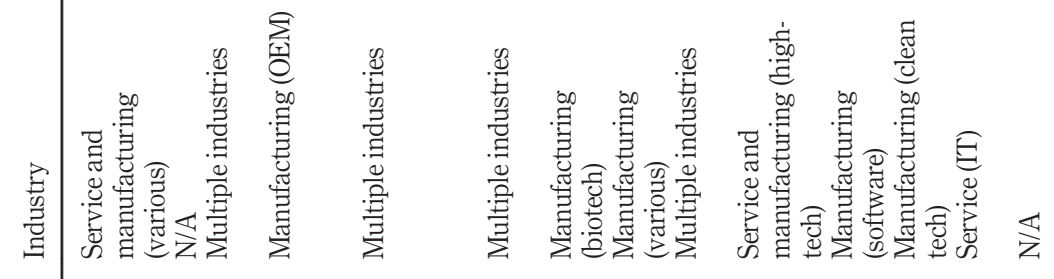

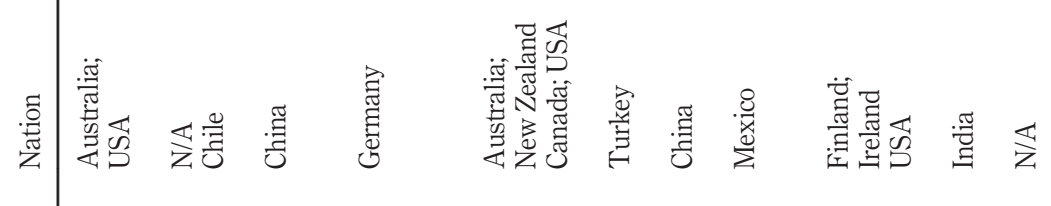

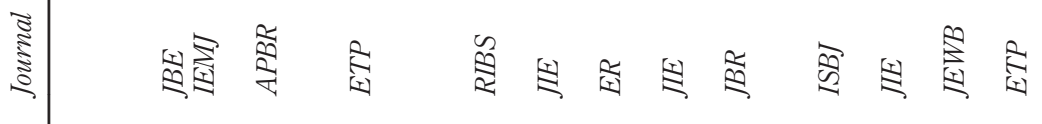

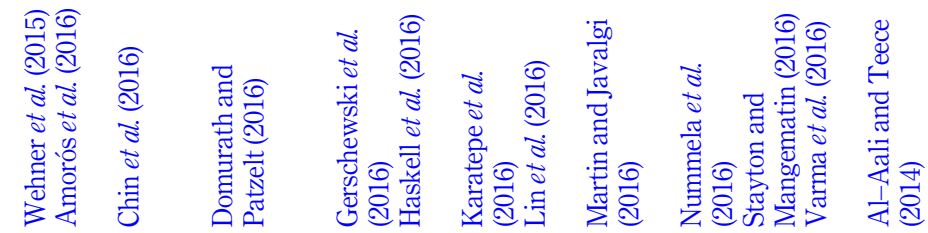




\section{RIBS}

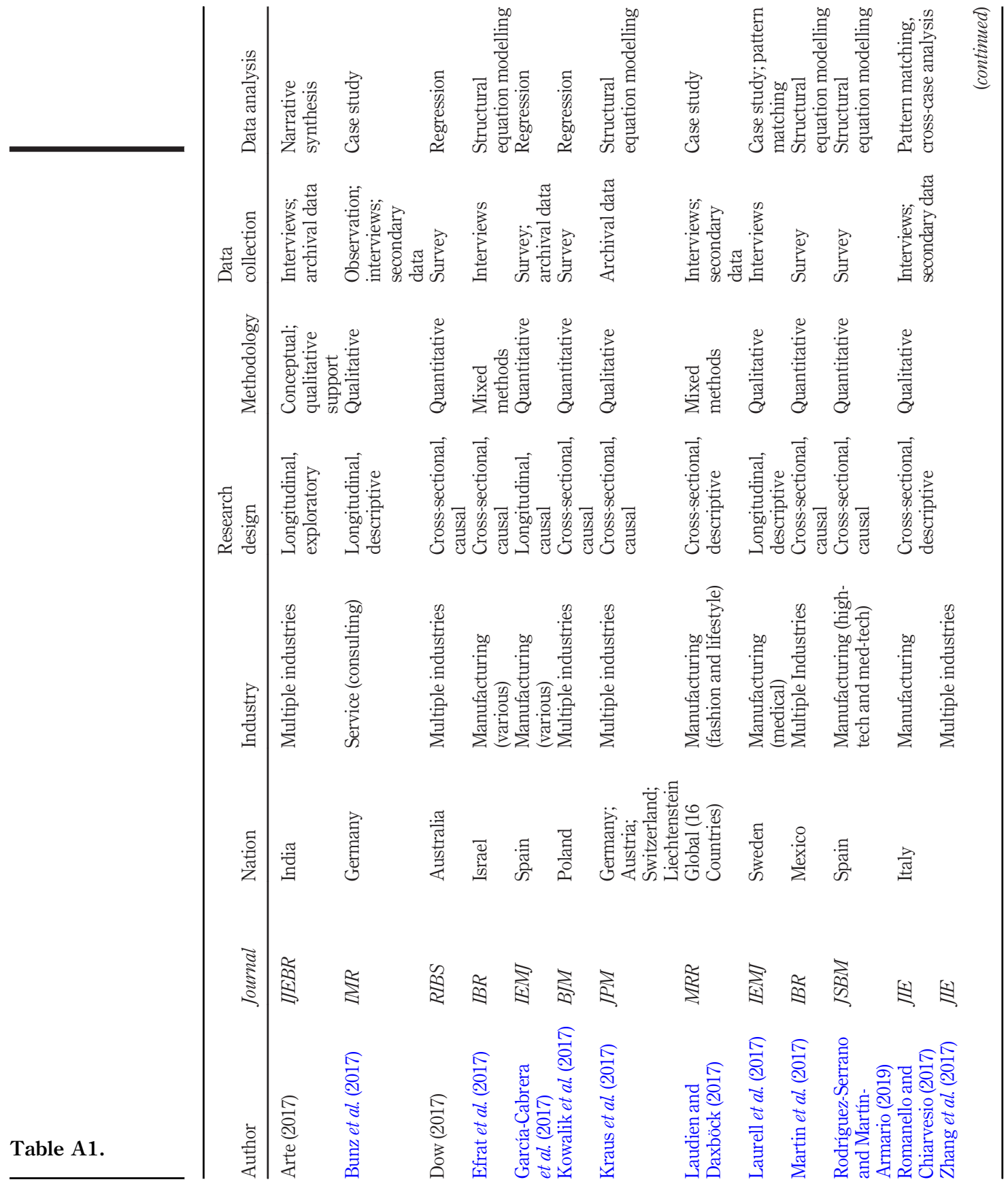


Review and

synthesis

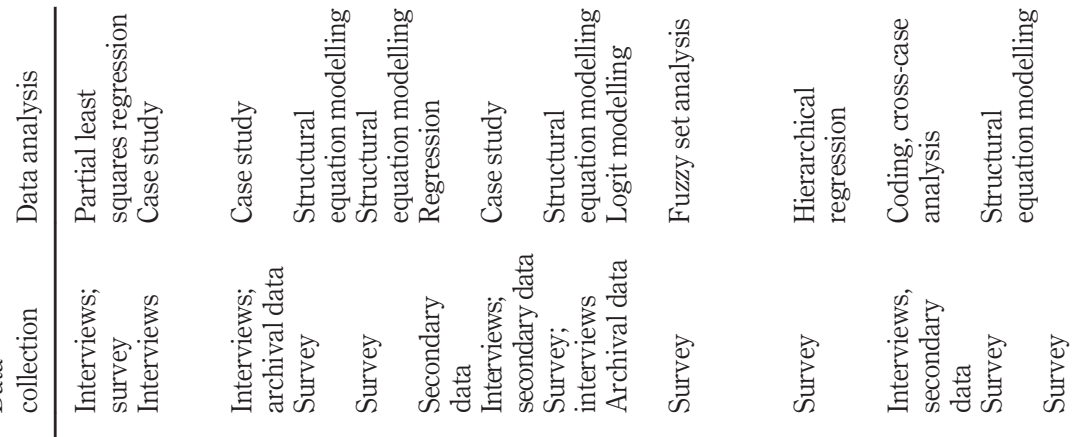

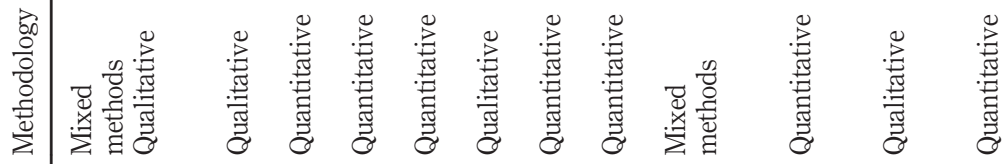

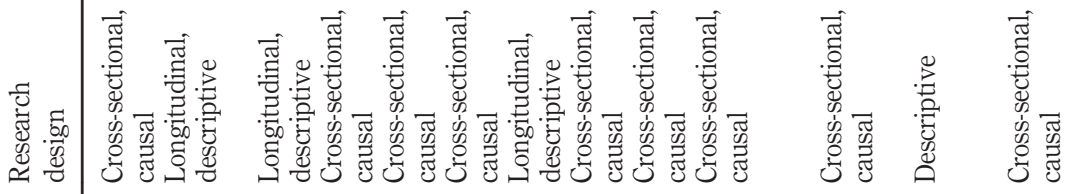

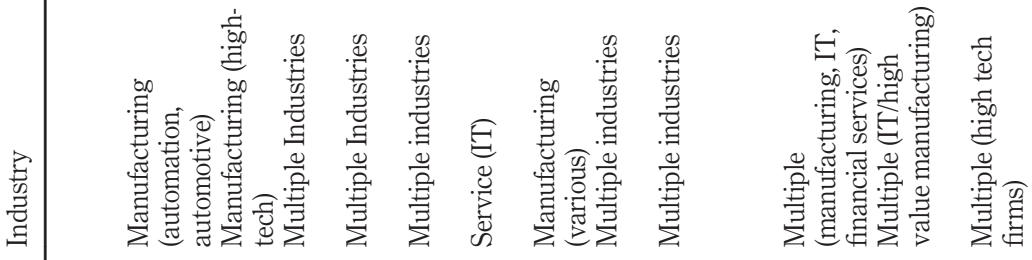

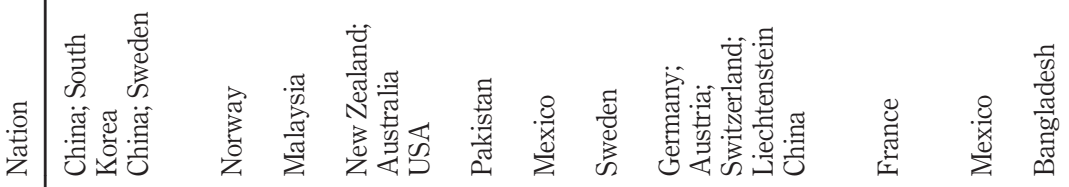

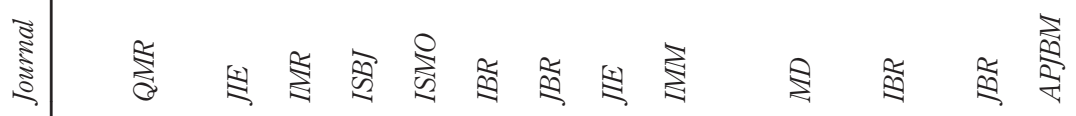

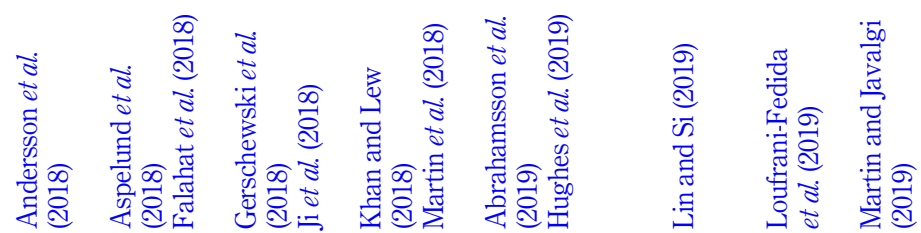

Table A1. 


\section{RIBS}

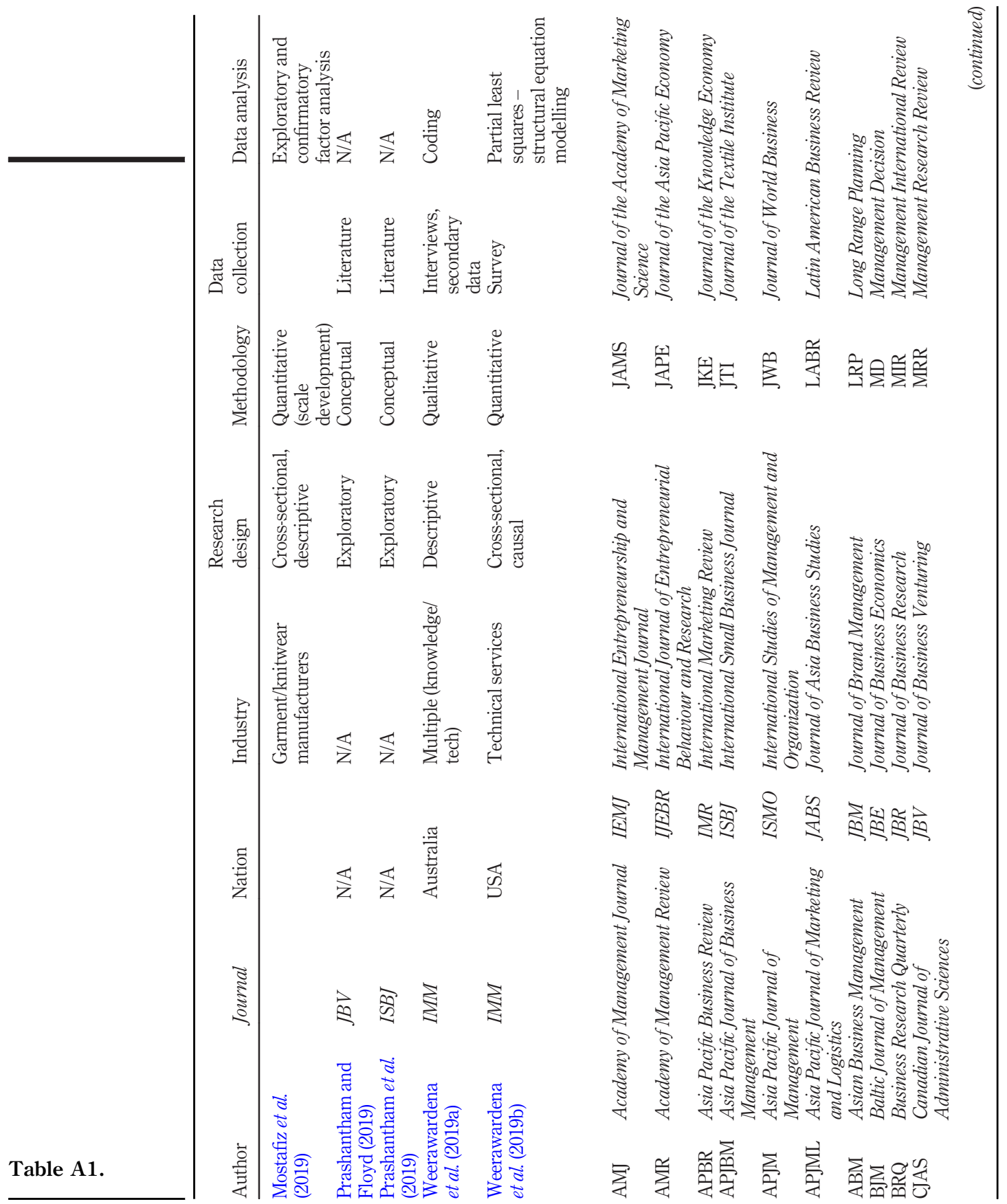


Review and synthesis

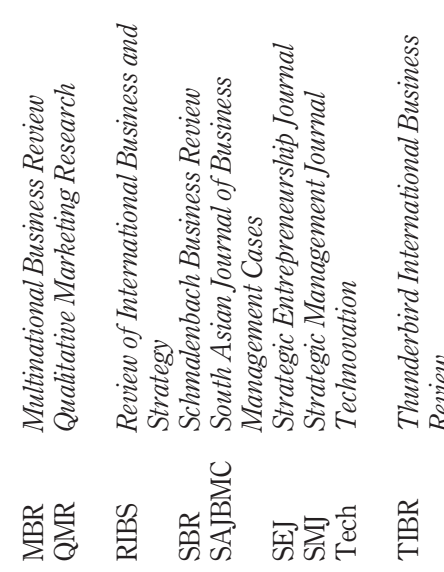

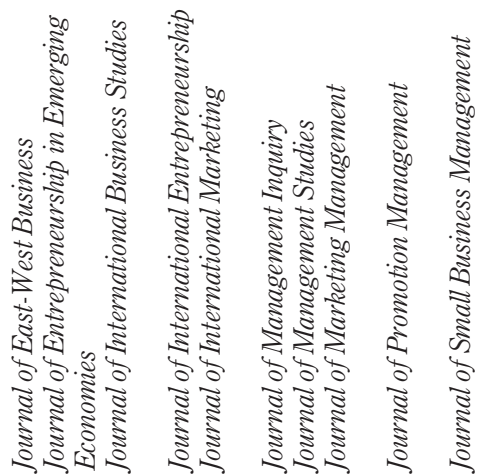

这这 婇

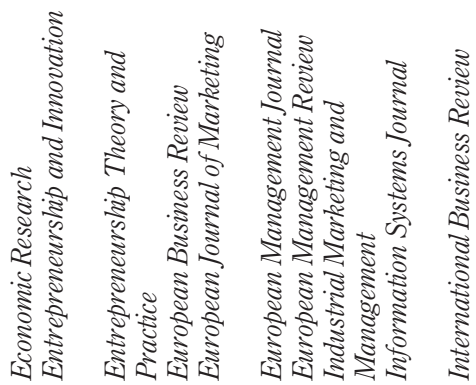

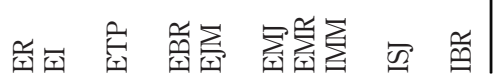


RIBS

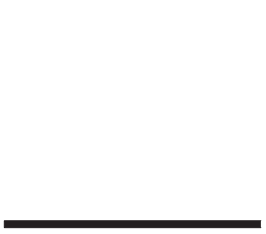

Figure A1.

Capabilities studied

\section{Appendix 2}

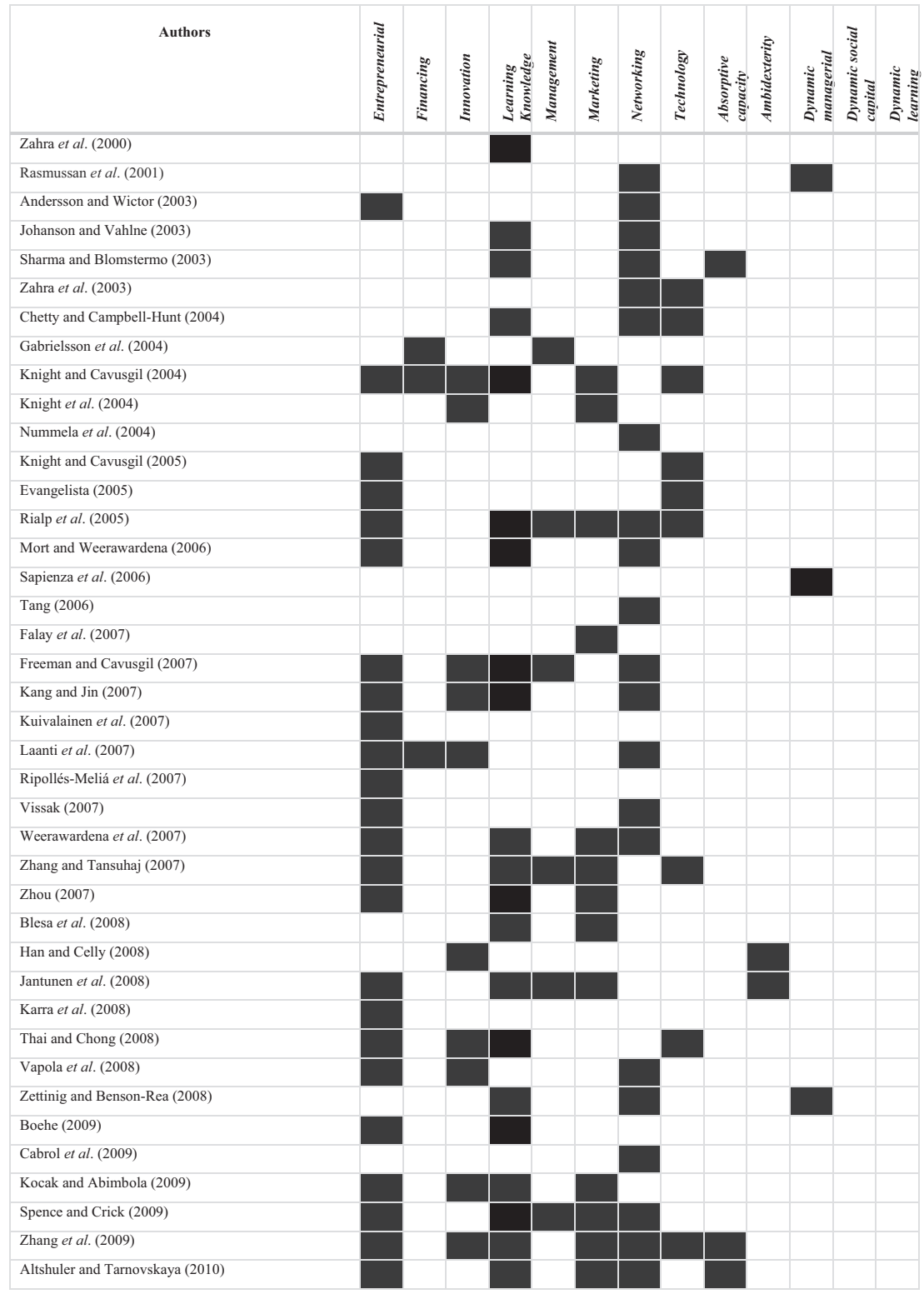

(continued) 


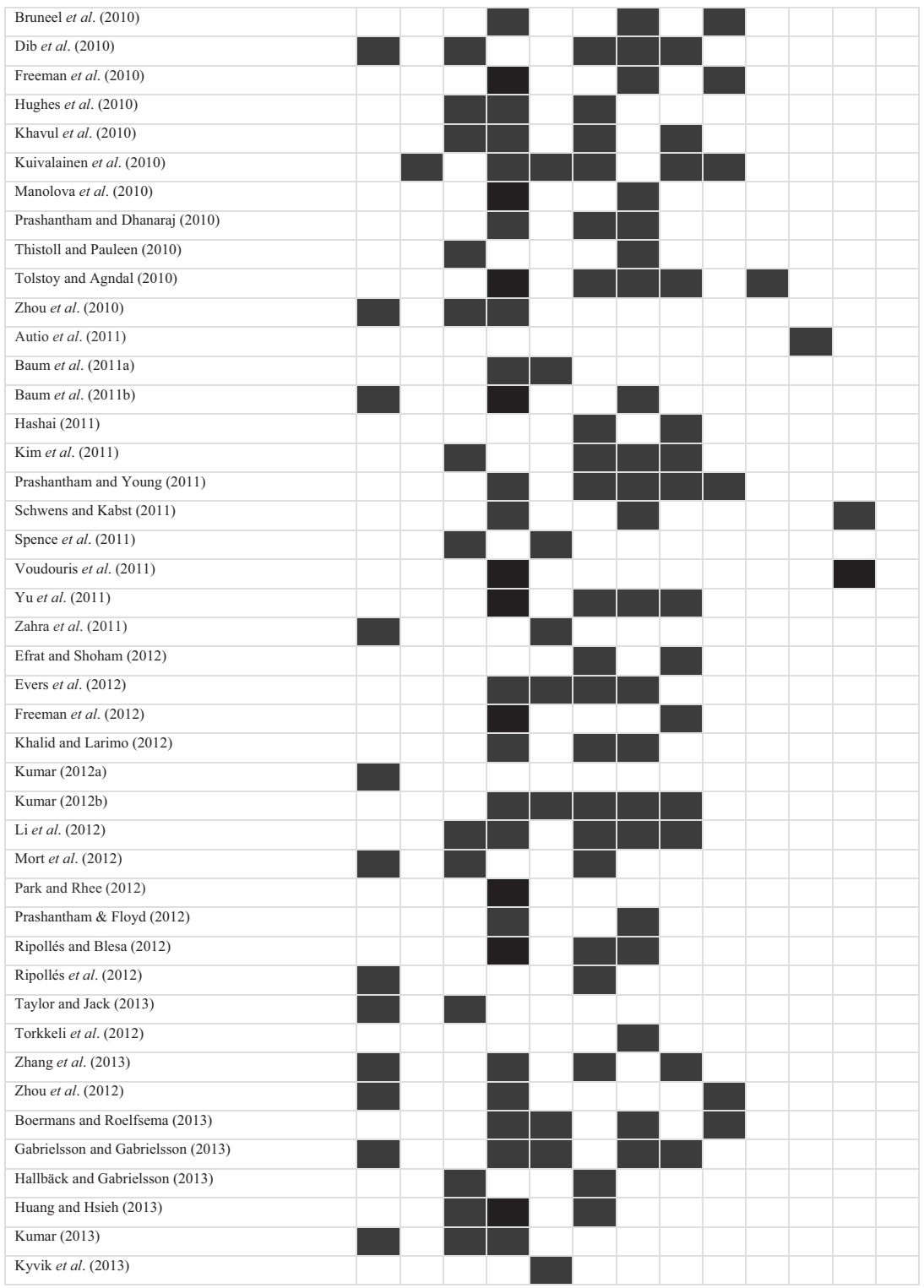

Review and synthesis

Kuivalainen et al. (2010)

Manolova et al. (2010)

Prashantham and Dhanaraj (2010)

Thistoll and Pauleen (2010)

Tolstoy and Agndal (2010)

Baum et al. (2011b)

Hashai (2011)

Kim et al. (2011)

hantham and Young (2011)

Yu et al. (2011)

Zahra et al. (2011)

Efrat and Shoham (2012)

Evers et al. (2012)

Kumar (2012a)

Kumar (2012b)

Li et al. (2012)

Mort et al. (2012)

Park and Rhee (2012)

tham \& Floyd (2012)

Zhang et al. (2013)

Zhou et al. (2012)

Kumar (2013)

Kyvik et al. (2013) 


\section{RIBS}

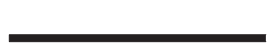

Figure A1.

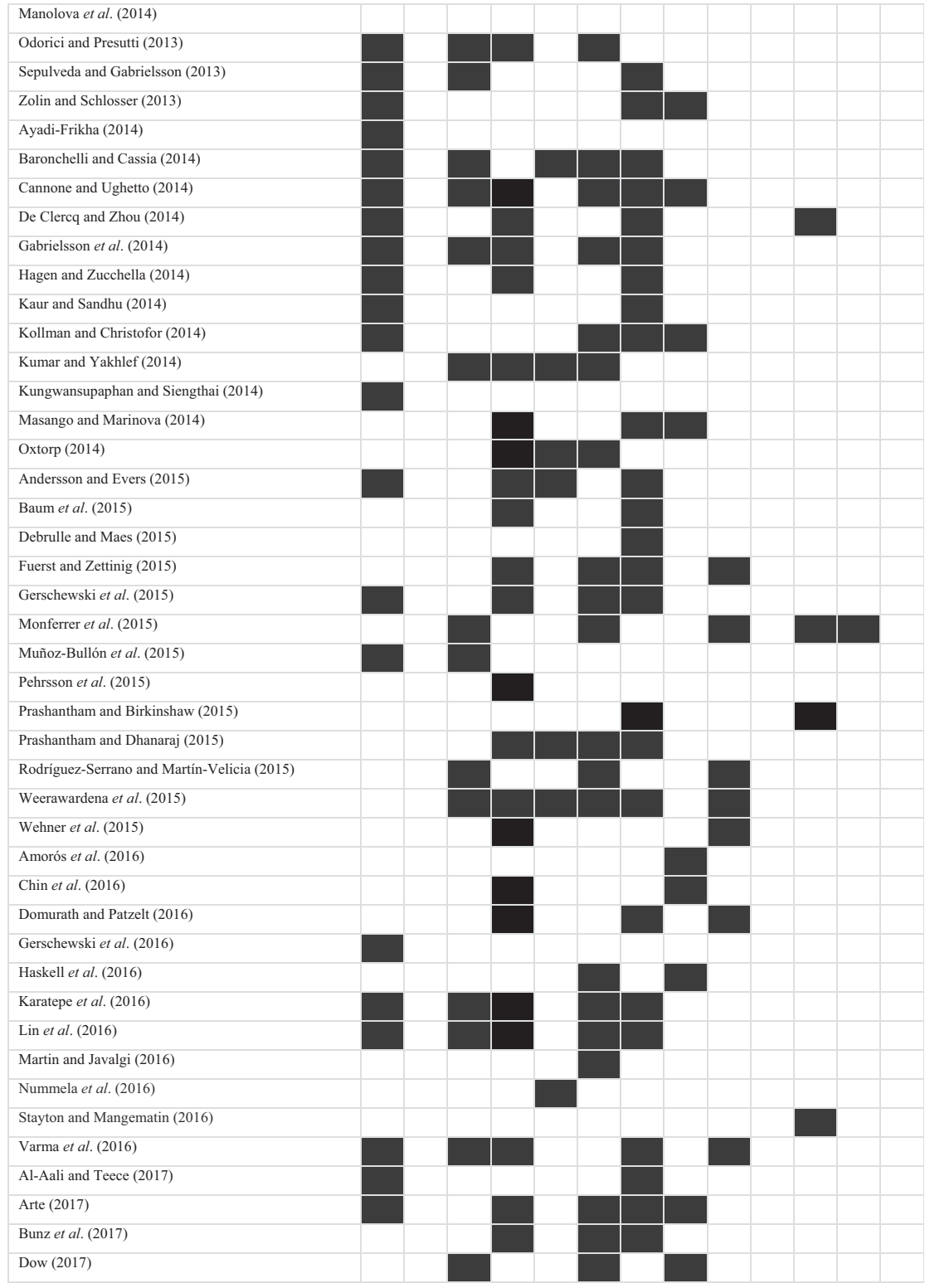

(continued) 


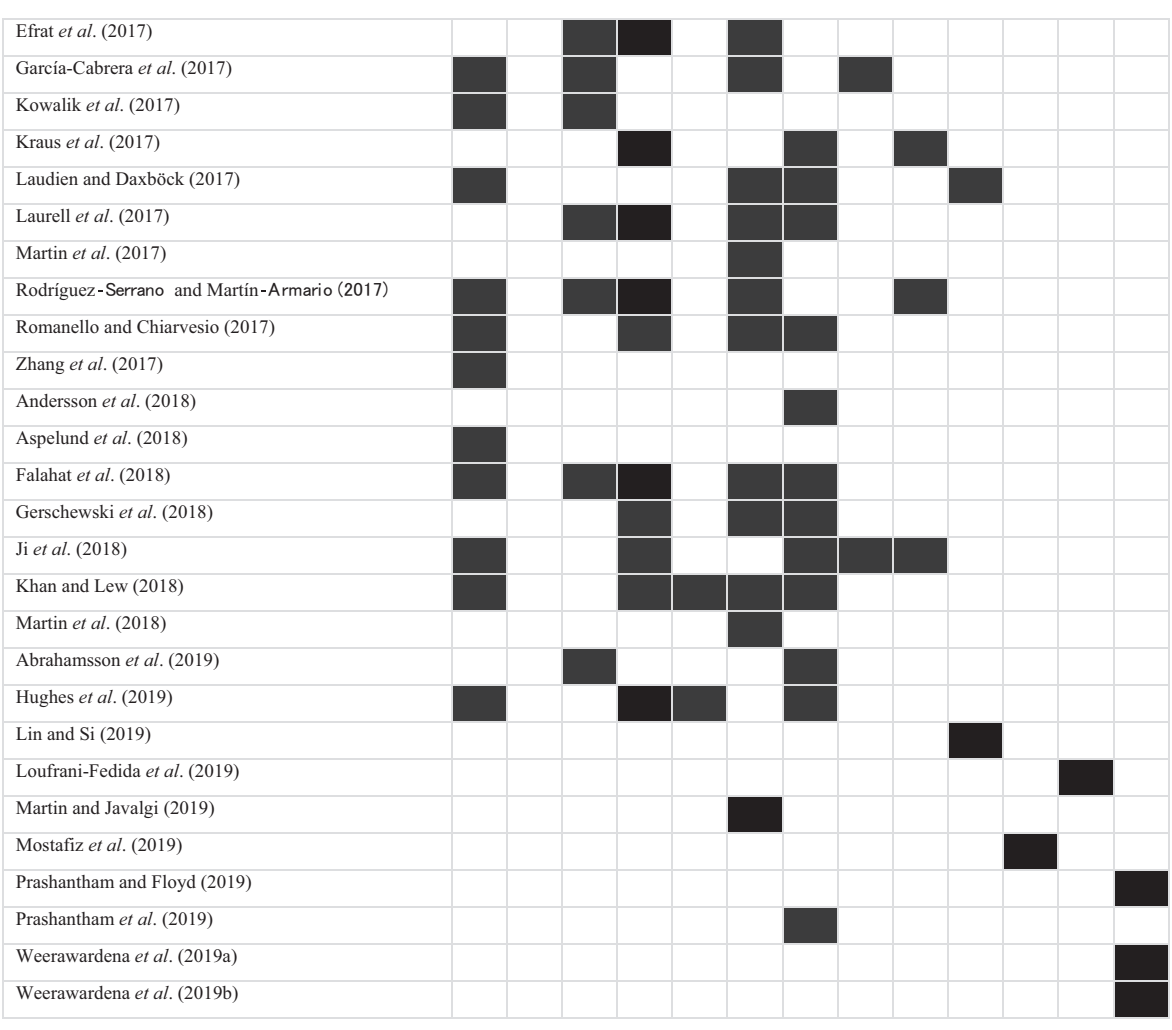

Review and synthesis

Kowalik et al. (2017)

Kraus et al. (2017)

Laudien and Daxböck (2017)

Laurell et al. (2017)

Martin et al. (2017)

Rodríguez-Serrano and Martín-Armario (2017)

Romanello and Chiarvesio (2017)

Zhang et al. (2017)

Andersson et al. (2018)

Aspelund et al. (2018)

Falahat et al. (2018)

Gerschewski et al. (2018)

Ji et al. (2018)

Khan and Lew (2018)

Martin et al. (2018)

Abrahamsson et al. (2019)

Hughes et al. (2019)

Lin and $\mathrm{Si}$ (2019)

Loufrani-Fedida et al. (2019)

Martin and Javalgi (2019)

Mostafiz et al. (2019)

Prashantham and Floyd (2019)

Prashantham et al. (2019)

rawardena et al. (2019a)

\section{Corresponding author}

Eldrede T. Kahiya can be contacted at:Eldrede.Kahiya@vuw.ac.nz

For instructions on how to order reprints of this article, please visit our website: www.emeraldgrouppublishing.com/licensing/reprints.htm

Or contact us for further details: permissions@emeraldinsight.com 